Article

\title{
Application of Rosemary and Eucalyptus Essential Oils and Their Main Component on the Preservation of Apple and Pear Fruits
}

\author{
Panayiota Xylia ${ }^{1}$, Antonios Chrysargyris ${ }^{1,2}$, Zienab F. R. Ahmed ${ }^{3}$ (D) and Nikolaos Tzortzakis ${ }^{1, *(D)}$ \\ 1 Department of Agricultural Sciences, Biotechnology and Food Science, Cyprus University of Technology, \\ Limassol 3036, Cyprus; pa.xylia@edu.cut.ac.cy (P.X.); a.chrysargyris@cut.ac.cy (A.C.) \\ 2 Department of Life Sciences, School of Sciences, European University of Cyprus, Nicosia 1516, Cyprus \\ 3 Integrative Agriculture Department, College of Agriculture and Veterinary Medicine, United Arab Emirates \\ University, Al Ain 15551, United Arab Emirates; zienab.ahmed@uaeu.ac.ae \\ * Correspondence: nikolaos.tzortzakis@cut.ac.cy; Tel.: +357-25002280
}

\section{check for} updates

Citation: Xylia, P.; Chrysargyris, A.; Ahmed, Z.F.R.; Tzortzakis, N.

Application of Rosemary and Eucalyptus Essential Oils and Their Main Component on the Preservation of Apple and Pear Fruits. Horticulturae 2021, 7, 479. https:/ / doi.org/10.3390/horticulturae7110479

Academic Editors: Alessandra Di Francesco, Gianfranco Romanazzi and Rosario Torres

Received: 9 October 2021

Accepted: 6 November 2021

Published: 9 November 2021

Publisher's Note: MDPI stays neutral with regard to jurisdictional claims in published maps and institutional affiliations.

Copyright: (c) 2021 by the authors. Licensee MDPI, Basel, Switzerland. This article is an open access article distributed under the terms and conditions of the Creative Commons Attribution (CC BY) license (https:/ / creativecommons.org/licenses/by/ $4.0 /)$.

\begin{abstract}
Nowadays, increase fruit losses are being reported due to the development of fungal postharvest diseases. In an attempt to reduce the use of synthetic fungicides, a turn towards natural products such as essential oils (EOs) and natural compounds has been made. The objective of this study was to investigate the effects of eucalyptus (Euc), rosemary (Ros) EO, their mixture (50:50 $v / v$ ) and their common main component (i.e., eucalyptol) on the quality parameters, fruit response and inhibition of blue rot (Penicillium expansum) in apple and pear fruits during their shelf life. The results of the present study revealed that fungal colony growth decreased in vitro with exposure at eucalyptus EO (Euc-300 $\mu \mathrm{L} / \mathrm{L})$, rosemary EO (Ros-300 $\mu \mathrm{L} / \mathrm{L})$ and their mixture (Euc + Ros 100 and $300 \mu \mathrm{L} / \mathrm{L})$. The exposure at Ros-100 $\mu \mathrm{L} / \mathrm{L}$ stimulated spore production, whilst Euc $+\operatorname{Ros}(100$ and $300 \mu \mathrm{L} / \mathrm{L})$ and eucalyptol (100 and $300 \mu \mathrm{L} / \mathrm{L})$ decreased spore germination. Moreover, the in vivo applied treatments resulted in decreased lesion growth of P. expansum in apple and pear fruits. Respiration rate increased with the application of Euc + Ros at $300 \mu \mathrm{L} / \mathrm{L}$ and eucalyptus EO (Euc-100 $\mu \mathrm{L} / \mathrm{L}$ and Euc-300 $\mu \mathrm{L} / \mathrm{L}$ ) for both assessed fruits. On the other hand, no significant differences were reported on apples and pears total soluble solids and acidity values. The application of Euc + Ros-300 $\mu \mathrm{L} / \mathrm{L}$ in apples increased hydrogen peroxide $\left(\mathrm{H}_{2} \mathrm{O}_{2}\right)$ levels, whilst Euc-100 and Euc-300 $\mu \mathrm{L} / \mathrm{L}$ increased lipid peroxidation levels. Regarding pear fruits, exposure to Euc- $100 \mu \mathrm{L} / \mathrm{L}$ and Ros- $100 \mu \mathrm{L} / \mathrm{L}$ resulted in increased $\mathrm{H}_{2} \mathrm{O}_{2}$ whereas, Euc-100 $\mu \mathrm{L} / \mathrm{L}$, Ros- $(100$ and $300 \mu \mathrm{L} / \mathrm{L})$ and eucalyptol (100 and $300 \mu \mathrm{L} / \mathrm{L})$ also increased lipid peroxidation. The findings of this study indicate that the investigated natural products can be explored for the preservation of fresh apples and pears, as alternative natural fungicides with consideration of the fresh produce quality attributes.
\end{abstract}

Keywords: apples; pears; essential oils; fruit quality; Penicillium expansum

\section{Introduction}

The consumption of fruit and vegetables as a part of a balanced and healthy diet is widely known. Diets with high intake of fruits and vegetables have been linked with healthpromoting and disease-preventive properties [1]. Consumption of fruits is recommended as they are sources of dietary fiber, vitamins (vitamin C, A, complex B), minerals and phytochemicals (including polyphenols and antioxidants) [1,2].

Apples and pears are both climacteric fruits and their ripening is regulated by ethylene emission/presence and increased respiration rates [3,4]. Moreover, during the ripening process of fruits, changes in firmness, color (optical quality), acidity and sugar content are reported [4]. These fruits are commonly stored at low temperatures for long periods, however during storage quality deteriorates and fruit nutritional value decreases [5,6]. In addition, the shelf life of fruits can be affected by numerous factors including pre- and postharvest 
practices, inappropriate storage conditions (i.e., high temperature and low humidity) that can lead to increase the metabolic activity of fruits during storage and transport [6-8].

A main limitation in fruits quality during storage and shelf life is the deterioration due to the development of postharvest diseases [9]. The major fungal pathogens that have been associated with quality losses of apple and pear fruits include Penicillium expansum (blue mold), Botrytis cinerea (gray mold), Alternaria sp. (Alternaria rot) and Rhizopus stolonifera (Rhizopus rot) $[9,10]$. In order for producers to control these diseases, the use of chemical fungicides (i.e., thiabendazole or azoxystrobin) has been employed for many years [11]. However, extensive use of these means has been proven to cause issues such as fungicide resistance, environmental pollution, as well as residues on fruits [11].

In recent years, restrictions on the use of chemical, synthetic fungicides have been applied in an attempt to eliminate their use and encourage the use of alternative, natural products, meeting the consumers demands for fresh produce free of harmful, chemical residues [10]. In this essence the investigation of natural products, including essential oils (EOs) from aromatic plants and herbs and other natural compounds has started gaining interest [12-14]. Many EOs have been proven to possess antifungal activities (among other properties), including thyme, oregano, cinnamon, clove, eucalyptus, rosemary, garlic EO [14-18]. This activity might be observed either by direct contact via immersion in a solution or by vapor application $[12,13,19]$. Moreover, natural compounds from plants secondary metabolisms have been investigated for their antifungal properties and the results are promising [20]. These compounds include compounds such as thymol, eugenol, carvone and eucalyptol among others [21].

Previous studies have reported the use of EOs on fresh produce with promising outcomes. Rosemary and eucalyptus EOs have been used during postharvest storage of fruits such as strawberry, tomato, mandarin, apples and grapes, providing decreases in disease development in those products [11,18,22-24]. For instance, the use of rosemary, cinnamon, citronella and clove EOs on 'Fuji' apples suppressed the growth of P. expansum [18].

When using EOs, one must consider that their efficacy against fungal pathogens (as well as other microorganisms) depends on their composition, concentration, application method and time, pathogen species, as well as the properties of the product being applied to [18]. Moreover, there have been reports that high EO concentrations might adversely affect quality attributes such as the sensory properties (i.e., aroma, taste, color) of the treated fresh produce [12]. Thus, it is essential that the applied EOs on fresh produce are able to eliminate the development of postharvest diseases and at the same time they can improve and/or maintain the quality attributes of the treated products [22].

The aim of this study was to evaluate the efficacy of rosemary and eucalyptus EO, their mixture (50:50 $\mathrm{v} / \mathrm{v}$ ) and eucalyptol (their main component) against P. expansum and the effects on the quality attributes, as well as fruit response of inoculated apples and pears during their shelf life.

\section{Materials and Methods}

\subsection{Plant Material and Inoculum Preparation}

Mature apple (cv. Granny Smith Verona Delizia Verde) and pear (cv. d' Anjou) fruits were obtained from a local market (Limassol, Cyprus). Fruits were selected for their uniformity (size, appearance) and were free of any physical defects. Prior use, fruits were surface disinfected with chlorinated water $(0.05 \% v / v)$ to eliminate the microbial load, and then fruits were washed three times with distilled water and left to dry at room temperature.

Eucalyptus (Eucalyptus globulus L.) and rosemary (Rosmarinus officinalis L.) plants were collected from the experimental farm of Cyprus University of Technology and aged of nine and three years old, respectively. Plant tissue was dried at $42{ }^{\circ} \mathrm{C}$ through an air-ventilated oven, till constant weight. EOs were obtained from hydrodistilation using a Clevenger apparatus for $3 \mathrm{~h}$ and the determination of EOs composition was performed through Gas Chromatography-Mass Spectrometry (GCMS; GC/MSQP-2010 Plus, Shimadzu, Tokyo, Japan) as previously described by Chrysargyris et al. [25]. The main compounds of eu- 
calyptus EO were eucalyptol (85\%), limonene $(6 \%)$ and $p$-cymene $(6 \%)$, while the main compounds of rosemary EO were eucalyptol (37\%), camphor $(18 \%)$ and $\alpha$-pinene $(10 \%)$. A mixture of the two EOs consisted of 50:50 (v/v) eucalyptus and rosemary was also prepared. Eucalyptol (Sigma-Aldrich, Darmstadt, Germany) was used as the main component of both EOs tested at $61 \%$, which is the percentage on the 50:50 (v/v) mixture of the two EOs. Therefore, the following nine treatments were tested: (i) control (without EO), (ii) eucalyptus EO at $100 \mu \mathrm{L} / \mathrm{L}$ (Euc-100 $\mu \mathrm{L} / \mathrm{L})$, (iii) eucalyptus EO at $300 \mu \mathrm{L} / \mathrm{L}$ (Euc-300 $\mu \mathrm{L} / \mathrm{L}$ ), (iv) rosemary $\mathrm{EO}$ at $100 \mu \mathrm{L} / \mathrm{L}(\operatorname{Ros}-100 \mu \mathrm{L} / \mathrm{L}),(\mathrm{v})$ rosemary EO at $300 \mu \mathrm{L} / \mathrm{L}$ (Ros-300 $\mu \mathrm{L} / \mathrm{L})$, (vi) eucalyptus and rosemary EO mixture at $100 \mu \mathrm{L} / \mathrm{L}$ (Euc + Ros-100 $\mu \mathrm{L} / \mathrm{L})$, (vii) eucalyptus and rosemary EO mixture at $300 \mu \mathrm{L} / \mathrm{L}$ (Euc + Ros-300 $\mu \mathrm{L} / \mathrm{L})$, (viii) eucalyptol at $100 \mu \mathrm{L} / \mathrm{L}$ (Eucalyptol-100 $\mu \mathrm{L} / \mathrm{L}$ ) and (ix) eucalyptol at $300 \mu \mathrm{L} / \mathrm{L}$ (Eucalyptol-300 $\mu \mathrm{L} / \mathrm{L}$ ).

Penicillium expansum was obtained from Department of Postharvest Science, Agricultural Research Organization-the Volcani Center, Rishon Le Tsiyon, Israel. Fresh P. expansum cultures were prepared by subculturing plugs on potato dextrose agar (PDA, HiMedia, Mumbai, India) and incubation in the dark at $25^{\circ} \mathrm{C}$ for one week.

\subsection{In Vitro Evaluation of the EOs}

One mycelial plug $\left(0.2 \mathrm{~cm}^{2}\right)$ from the periphery of a one week-old culture (P. expansum; prepared as described above) was placed in the center of a Petri dish containing $20 \mathrm{~mL}$ of PDA [26]. On the inside of the dish's lid a $1 \mathrm{~cm}^{2}$ sterile filter paper was placed carrying the appropriate volume of individual EOs, mixture of EOs and eucalyptol corresponding to the tested concentrations (0-100-300 $\mu \mathrm{L} / \mathrm{L})$. Control treatment was considered by adding $\mathrm{dH}_{2} \mathrm{O}$ at the filter paper. Plates were closed, sealed with parafilm, remained for $1 \mathrm{~h}$ at room temperature for successful EOs vaporization and placed inverted for incubation at $7{ }^{\circ} \mathrm{C}$ and 13 days.

Colony growth was monitored by measuring colony diameter every other day (day 2, $4,6,8,11,13$ ) and results were expressed in $\mathrm{cm}^{2}$. Plates were further left for incubation at the same conditions until fungi sporulation. Spore production was assessed on the 21st day of the experiment. Controls were the plates without vaporized compounds.

Following fungal colony growth evaluation, plates remained at $7{ }^{\circ} \mathrm{C}$ till spore formation. Spores were collected using an L-shaped spreader and $5 \mathrm{~mL}$ sterile $\mathrm{dH}_{2} \mathrm{O}$ (with $0.1 \%$ Tween $80 \mathrm{v} / \mathrm{v}$ ), scraping the fungal mycelium (21-days old P. expansum mycelium) and the spore suspension collected from the Petri dish was concentrated to $1 \mathrm{~mL}$ final volume. Using a haemocytometer slide, spores were counted under a microscope and results were expressed as spores $\times 10^{6} / \mathrm{mL}$.

Harvested spores from the plates exposed to either control or vaporized (eucalyptus oil, rosemary oil, their mixtures and eucalyptol) compounds were examined for their viability (germination). Spore suspension (prepared as mentioned above) $(200 \mu \mathrm{L})$ was inoculated onto $10 \mathrm{~mL}$ solidified PDA medium and plates were incubated at $25^{\circ} \mathrm{C}$ for $24 \mathrm{~h}$. After incubation, 100 spores were counted (for each replication) and results were recorded as percentage of germinated spores (\% spore germination).

\subsection{In Vivo Evaluation of the EOs}

\subsubsection{Fruit Preparation and Inoculation}

Fruits (apples and pears) were wounded with a sterile scalpel and inoculated with a mycelial plug $\left(0.1 \mathrm{~cm}^{2}\right)$ from the periphery of a 7-day old P. expansum culture. Inoculated fruits were left at room temperature (RT) for $2 \mathrm{~h}$, in order to allow the fungus to attach in wound area. Four fruits (four replications) per treatment were placed, enclosed in a $5 \mathrm{~L}$ capacity polypropylene plastic container and exposed to volatiles at concentrations 0-100-300 $\mathrm{LL} / \mathrm{L}$ for approx. $1 \mathrm{~h}$ at RT (to let EOs evaporate). Containers were then, placed at $7^{\circ} \mathrm{C}$ and kept for 5 and 8 days (for pears and apples, respectively) in order to evaluate the disease progress at chilled conditions. Afterwards, containers were transferred at RT until sampling day (day 11 and 15 for pears and apples, respectively) in order to evaluate 
the disease progress under shelf-life conditions. Fruits were kept during all experiment in the plastic container, for control and inoculated during the application of the EOs.

\subsubsection{Lesion Growth}

Lesion growth area was monitored throughout storage (up to 11 and 15 days for pears and apples, respectively), by measuring lesion diameters (average of three measures/lesion) and results were presented in $\mathrm{cm}^{2}$.

\subsubsection{Effects on Fruit Quality Attributes}

Prior treatments (day 0 ) and at the end of storage (day 11 and 15 for pears and apples, respectively), several fruit quality parameters and damage indicators were estimated. Fruit respiration rate was estimated using a dual gas analyser (GCS 250 Analyzer, International Control Analyser Ltd., Kent, UK) by measuring the $\mathrm{CO}_{2}$ produced from one fruit enclosed for $1 \mathrm{~h}$ in an air tight plastic container as previously described by Tzortzakis [27]. Fruit volume and weight were measured and results were expressed as $\mathrm{mL} \mathrm{CO}_{2}$ per $\mathrm{kg}$ per $\mathrm{h}\left(\mathrm{mL} \mathrm{CO}_{2} / \mathrm{kg} / \mathrm{h}\right)$. Fruit firmness was evaluated by measuring the amount of force (in Newtons; N) required to penetrate fruits pericarp, using a plunger of $3 \mathrm{~mm}$ in diameter at a speed of $2 \mathrm{~mm} / \mathrm{s}$ and the penetration depth was $5 \mathrm{~mm}$, using a texture analyzer (TA.XT plus, Stable Micro Systems, Surrey, UK). Total soluble solids (TSS) were determined by a digital refractometer (Sper Scientific 300017, Scottsdale, AZ, USA) and results were expressed as ${ }^{\circ}$ Brix. The determination of fruits titratable acidity (TA) was performed by potentiometric titration with a food and beverage titrator (Mettler Toledo DL22, MettlerToledo AG, Schwerzenbach, Switzerland) using 0.1 N NaOH until the end-point ( $\mathrm{pH}$ 8.2) and results were expressed as $g$ of malic acid per $\mathrm{L}$ of juice ( $\mathrm{g}$ malic acid/L). Fruit ripening index was computed as the ratio of TSS/TA. Ascorbic acid (AA) content was estimated by the 2,6-dichloroindophenol titrimetric method [28] and results were expressed as g AA per $100 \mathrm{~g}$ of fresh weight (g AA/100 g).

\subsubsection{Determination of Damage Index}

For the determination of damage index, hydrogen peroxide production and lipid peroxidation were investigated by extracting $0.15 \mathrm{~g}$ of frozen grinded tissue with $0.1 \%$ $(w / v)$ trichloroacetic acid (TCA). After centrifuging at $15,000 \times g$ for $15 \mathrm{~min}$ at $4{ }^{\circ} \mathrm{C}$, the supernatant was used for analysis. The production of hydrogen peroxide $\left(\mathrm{H}_{2} \mathrm{O}_{2}\right)$ was assessed as previously described by Loreto and Velikova [29]. Briefly, an aliquot of the supernatant was mixed with $10 \mathrm{mM}$ potassium phosphate buffer ( $\mathrm{pH}$ 7.0) and $1 \mathrm{M}$ potassium iodide (KI). Measuring the absorbance of the reaction at $390 \mathrm{~nm}$, the results were expressed as $\mu \mathrm{mol} \mathrm{H}_{2} \mathrm{O}_{2}$ per $\mathrm{g}$ of fresh weight $(\mu \mathrm{mol} / \mathrm{g})$. The determination of lipid peroxidation was performed according to Chrysargyris et al. [30] by mixing an aliquot of the supernatant with $0.5 \%$ thiobarbituric acid (TBA) in $20 \% \mathrm{TCA}$, incubating the reaction at $95^{\circ} \mathrm{C}$ for $25 \mathrm{~min}$, measuring the absorbance at $532 \mathrm{~nm}$ (discarding the non-specific absorbance at $600 \mathrm{~nm}$ ) and expressing the results and nmol MDA per $\mathrm{g}$ of fresh weight $(\mathrm{nmol} / \mathrm{g})$.

\subsubsection{Sensory Evaluation}

Fresh produce marketability, aroma and appearance were recorded by five observers to compare the external visual aspect and marketability of treated and control fresh produce after 11 and 15 days for pears and apples, respectively. Aroma was evaluated by using a 1-10 scale, with 1: bad aroma but not EOs odor; 3: EOs odor with some unpleasant smell; 5: EOs smell but it is pleasant; 8: less fruit-like; 10: intense fruit-like. Appearance was evaluated by using a $1-10$ scale, with 1 : browning color of more than $50 \% ; 3: 10-50 \%$ brown color; 5: <10\% color changes; 8: lighter colour; 10: fruit like colour. Marketability was evaluated by using a 1-10 scale, with 1: not marketable quality (i.e., malformation, cracking, brown color); 3: low marketable with malformation; 5: marketable with few defects i.e., slight decolorization (medium quality); 8: marketable (good quality); 10: marketable with no defects (extra quality). 


\subsection{Statistical Analysis}

Data were analyzed using IBM SPSS version 25. First, data were subjected to one-way analysis of variance (one-way ANOVA) comparing the treatment means at the end day and performing Duncan's multiple range test $(p=0.05)$. In addition, paired samples $t$-test was used for comparing initial and end day control samples. All analyses were performed in triplicates.

\section{Results}

\subsection{In Vitro}

\subsubsection{Effects on Colony Growth}

The effects of the EOs, their mixture and eucalyptol on P. expansum colony growth are illustrated in Figure 1. On the last day (day 13) decreased colony growth was observed with Euc-300 $\mu \mathrm{L} / \mathrm{L}$ and Ros-300 $\mu \mathrm{L} / \mathrm{L}$ compared to the control (Figure 1A,B). Significant colony decrease was observed when oils from eucalyptus and rosemary were mixed at $50: 50 \%(v / v)$ ratio, in case of Euc + Ros-100 $\mu \mathrm{L} / \mathrm{L}$ and Euc + Ros-300 $\mu \mathrm{L} / \mathrm{L}$ (Figure 1C). On the other hand, eucalyptol did not affect the fungal colony growth as no significant differences were reported between both eucalyptol concentrations (Eucalyptol-100 $\mu \mathrm{L} / \mathrm{L}$ and Eucalyptol-300 $\mu \mathrm{L} / \mathrm{L}$ ) and control (Figure 1D,E).

\subsubsection{Effects on Spore Production and Spore Germination}

Figure 2 shows the effects of eucalyptus and rosemary EOs, their mixture and eucalyptol on spore production of P. expansum. The application of eucalyptus EO (Euc), its combination with rosemary EO (Euc + Ros; 50:50, v/v) and eucalyptol did not show significant difference between their concentrations or with the control (for each one) (Figure 2A,C,D). Interestingly, when P. expansum was exposed to rosemary EO at $100 \mu \mathrm{L} / \mathrm{L}$ (Ros-100 $\mu \mathrm{L} / \mathrm{L})$, spore production was stimulated compared to Ros-300 $\mu \mathrm{L} / \mathrm{L}$ and non-treated (control) PDA media (Figure 2B).
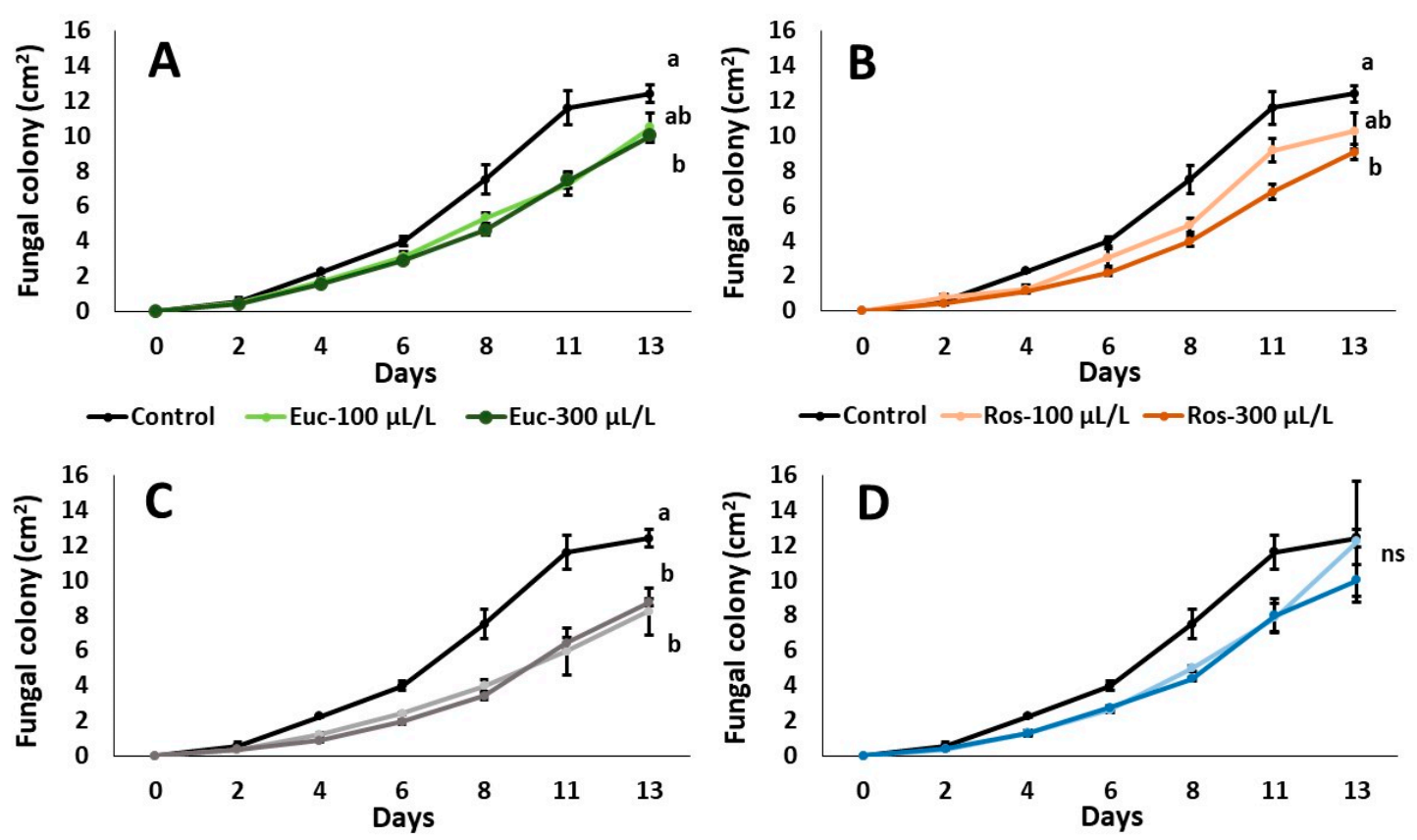

$\rightarrow$ Control $\rightarrow$ Euc+Ros-100 $\mu \mathrm{L} / \mathrm{L} \rightarrow$ Euc+Ros-300 $\mu \mathrm{L} / \mathrm{L}$

$\rightarrow$ Control $\multimap$ Eucalyptol-100 $\mu \mathrm{L} / \mathrm{L} \sim$ Eucalyptol-300 $\mu \mathrm{L} / \mathrm{L}$

Figure 1. Cont. 


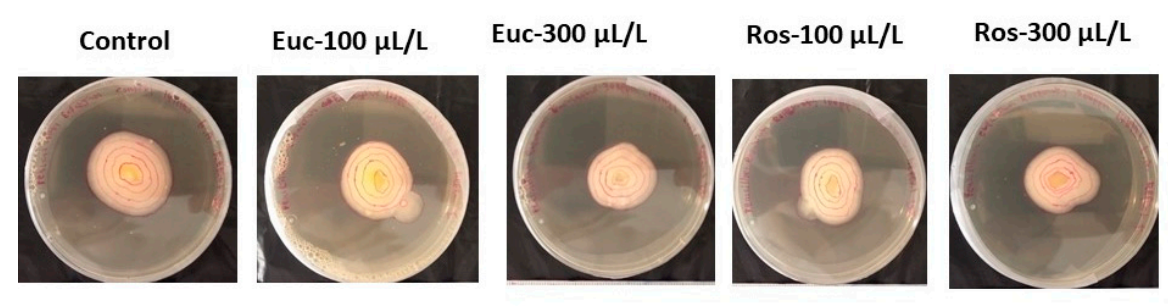

Euc-Ros-100 $\mu \mathrm{L} / \mathrm{L}$ Euc-Ros-300 $\mu \mathrm{L} / \mathrm{L}$ Eucalyptol-100 $\mu \mathrm{L} / \mathrm{L}$ Eucalyptol-300 $\mu \mathrm{L}$

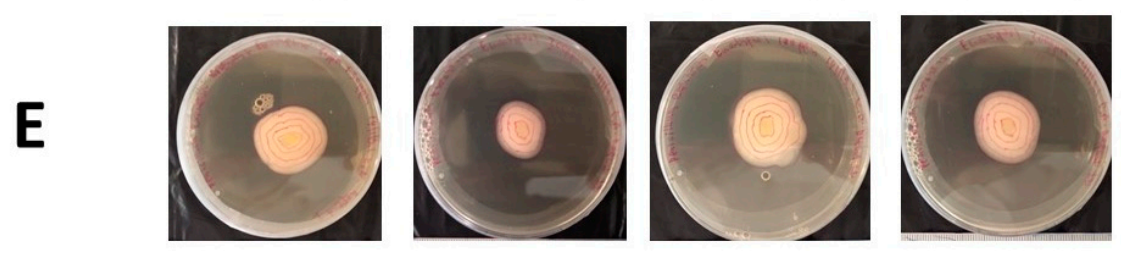

Figure 1. Effects of (A) eucalyptus EO (Euc), (B) rosemary EO (Ros), (C) their 50:50 mixture (Euc + Ros) and (D) eucalyptol on $P$. expansum colony growth on PDA medium at $7{ }^{\circ} \mathrm{C}$ for 13 days. Significant differences $(p<0.05)$ among treatments are represented with different Latin letters; ns indicates no significant differences among the treatments, on the last day. (E) Representative image is also presented.
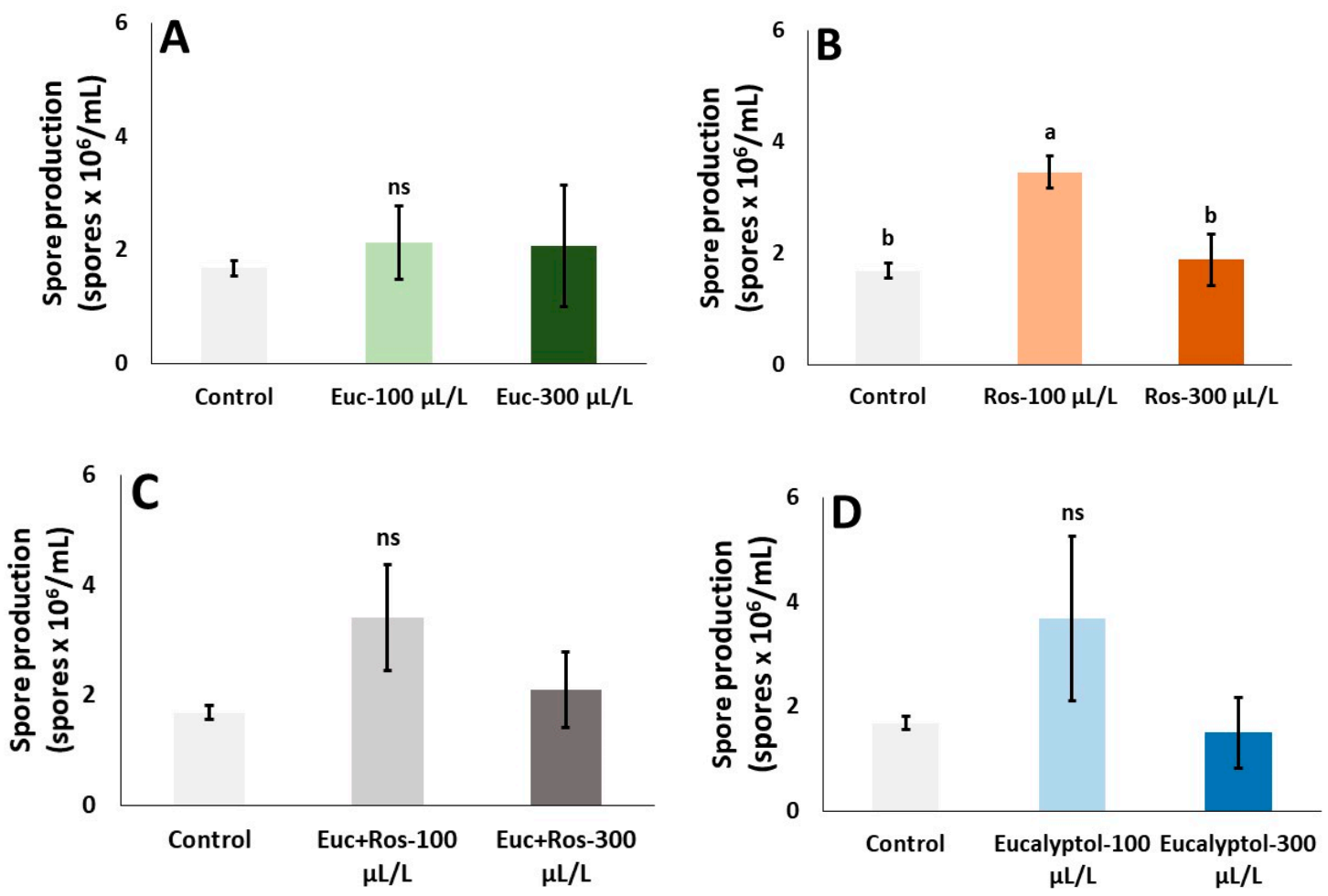

Figure 2. Effects of (A) eucalyptus EO (Euc), (B) rosemary EO (Ros), (C) their 50:50 mixture (Euc + Ros) and (D) eucalyptol on spore production of $P$. expansum grown on PDA medium at $7{ }^{\circ} \mathrm{C}$ for 13 days. Significant differences $(p<0.05)$ among treatments are represented with different Latin letters; ns indicates no significant differences among the treatments, on the last day.

Spore germination of P. expansum as affected by exposure to the two EOs, their mixture and eucalyptol is presented in Figure 3. Exposure to eucalyptus (Euc) and rosemary (Ros) EOs resulted in no significant differences compared to the control and between their concentrations, but a decrease trend on spore germination could be seen at the highest EOs levels (i.e., $300 \mu \mathrm{L} / \mathrm{L}$ ) (Figure $3 \mathrm{~A}, \mathrm{~B}$ ). Indeed, both concentrations of the EOs mixture (Euc + Ros) presented decreased spore viability compared to the control, with Euc + Ros at $300 \mu \mathrm{L} / \mathrm{L}$ showing the lower value (Figure $3 \mathrm{C}$ ). Similar to the EOs mixtures, eucalyptol 
application decreased spore germination in comparison to the control treatment, with Eucalyptol at $100 \mu \mathrm{L} / \mathrm{L}$ revealing lower spore germination (averaged in 85.2\%) compared to Eucalyptol at $300 \mu \mathrm{L} / \mathrm{L}$ (Figure 3D).
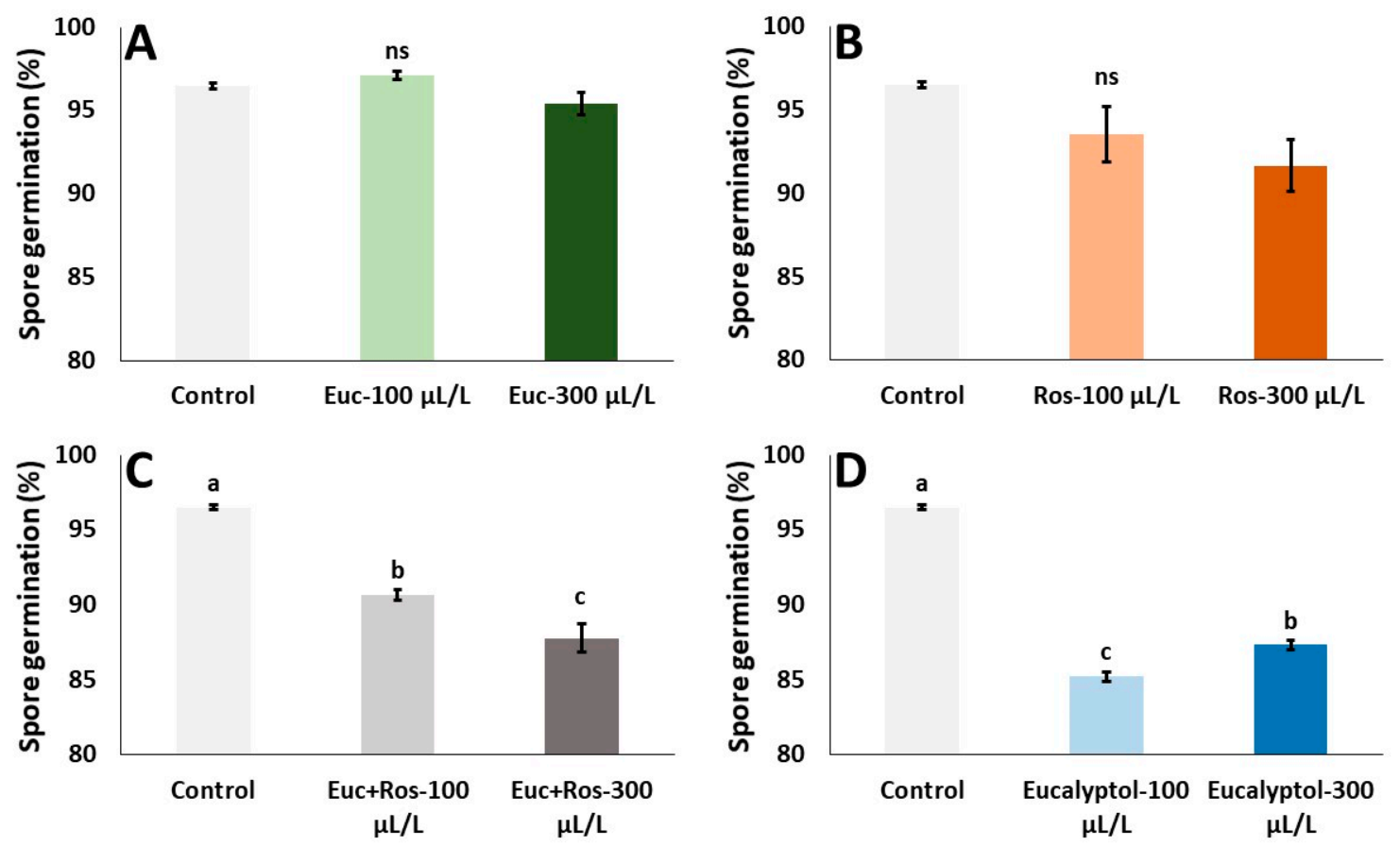

Figure 3. Effects of (A) eucalyptus EO (Euc), (B) rosemary EO (Ros), (C) their 50:50 mixture (Euc + Ros) and (D) eucalyptol on spore germination (\%) of P. expansum grown on PDA medium at $7{ }^{\circ} \mathrm{C}$ for 13 days. Significant differences $(p<0.05)$ among treatments are represented with different Latin letters; ns indicates no significant differences among the treatments.

\subsection{In Vivo}

\subsubsection{Effects on Lesion Growth}

The effects of the storage conditions and the EOs, their mixture and eucalyptol on lesion growth of P. expansum inoculated in apples and pears are illustrated in Figures 4 and 5 with the relevant representative images (Figures $4 \mathrm{E}$ and $5 \mathrm{E}$ ). Fungal growth was slowed during storage of 8 days at chilled temperatures $\left(7^{\circ} \mathrm{C}\right)$ but stimulated (approximately 8.1-fold) when fruits were stored at RT for an additional 7 days. P. expanusm was found to present decreased fungal growth (lesion growth) on apples when exposed to Euc-300 $\mu \mathrm{L} / \mathrm{L}$ compared to non-exposed to EO fruits, whilst EO of Euc-100 $\mu \mathrm{L} / \mathrm{L}$ stimulated the fungal growth as revealed higher lesion growth on the last day of storage (day 15) (Figure 4A). Similarly, EO of Ros-100 $\mu \mathrm{L} / \mathrm{L}$ stimulated fungal growth after 15 days of storage in comparison to control (Figure 4B). Interestingly, the combination of the two EOs (Euc + Ros) and eucalyptol reversed the fungal stimulation observed when individual EO was applied as no significant differences were found among the treated and non-treated fruits (Figure 4C,D).

Fungal growth on pear fruits decreased after treatment with Euc + Ros $300 \mu \mathrm{L} / \mathrm{L}$ compared to Euc $+\operatorname{Ros} 100 \mu \mathrm{L} / \mathrm{L}$, but did not differ from the control treatment by the last day of storage (Figure 5C). However, individual applications of eucalyptus EO, rosemary $\mathrm{EO}$ and eucalyptol in both concentrations, were found not to differ significantly between them or the control (Figure 5A,B,D). Similar to apples, fungal growth was slowed during storage of 8 days at chilled temperatures $\left(7^{\circ} \mathrm{C}\right)$ but stimulated (approximately 4.5 -fold) when fruits were stored at RT for an additional 7 days. 

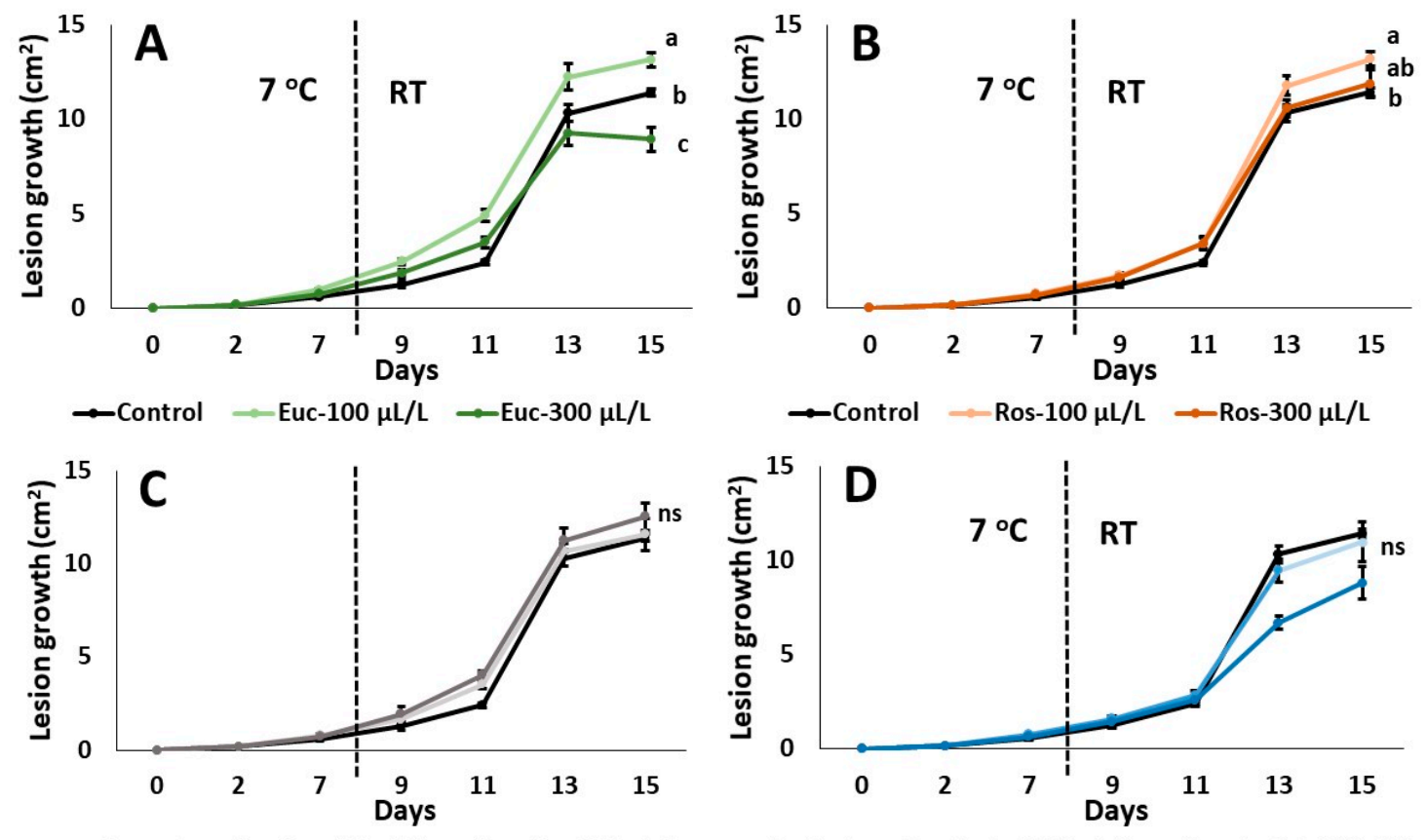

$\rightarrow$ Control $\rightarrow$ Euc+Ros-100 $\mu \mathrm{L} / \mathrm{L} \rightarrow$ Euc+Ros-300 $\mu \mathrm{L} / \mathrm{L}$

$\rightarrow$ Control $\rightarrow$ Eucalyptol-100 $\mu \mathrm{L} / \mathrm{L} \leadsto$ Eucalyptol-300 $\mu \mathrm{L} / \mathrm{L}$
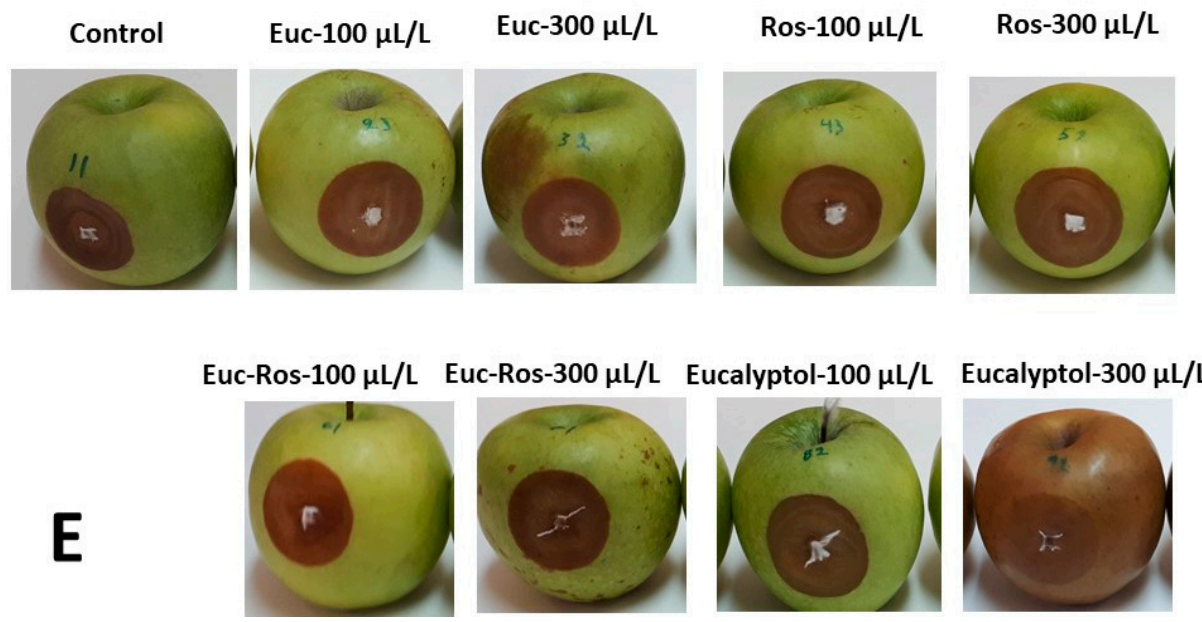

Figure 4. Effects of (A) eucalyptus EO (Euc), (B) rosemary EO (Ros), (C) their 50:50 mixture (Euc + Ros) and (D) eucalyptol on lesion growth of $P$. expansum grown on apple fruits stored at $7{ }^{\circ} \mathrm{C}$ for 8 days and subsequently at RT up to 15 days. Significant differences $(p<0.05)$ among treatments are represented with different Latin letters; ns indicates no significant differences among the treatments, on the last day. (E) Representative image is also presented. 

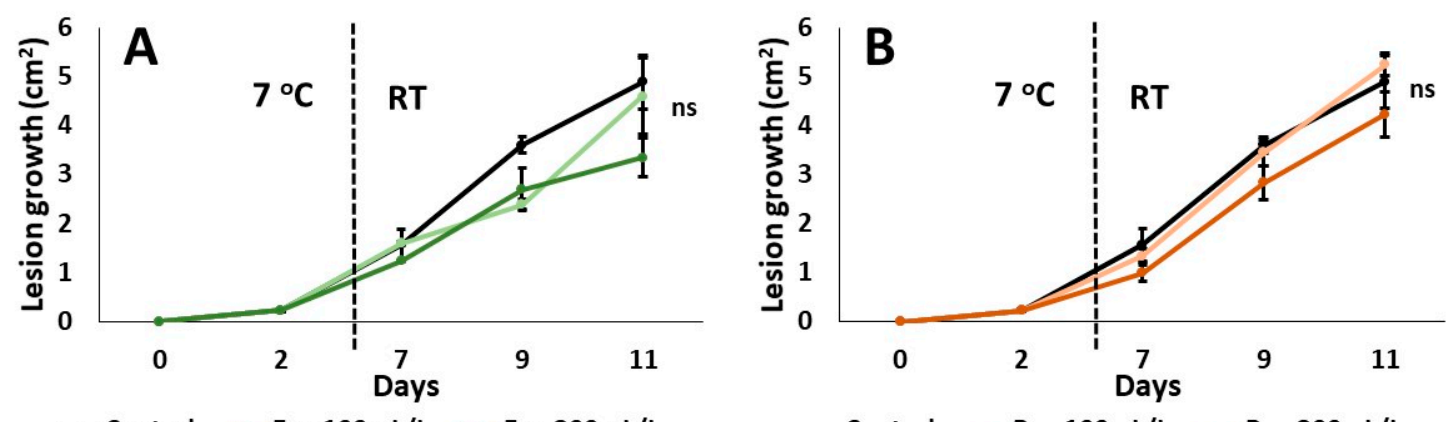

$\rightarrow$ Control $\rightarrow$ Euc-100 $\mu \mathrm{L} / \mathrm{L} \rightarrow$ Euc-300 $\mu \mathrm{L} / \mathrm{L}$
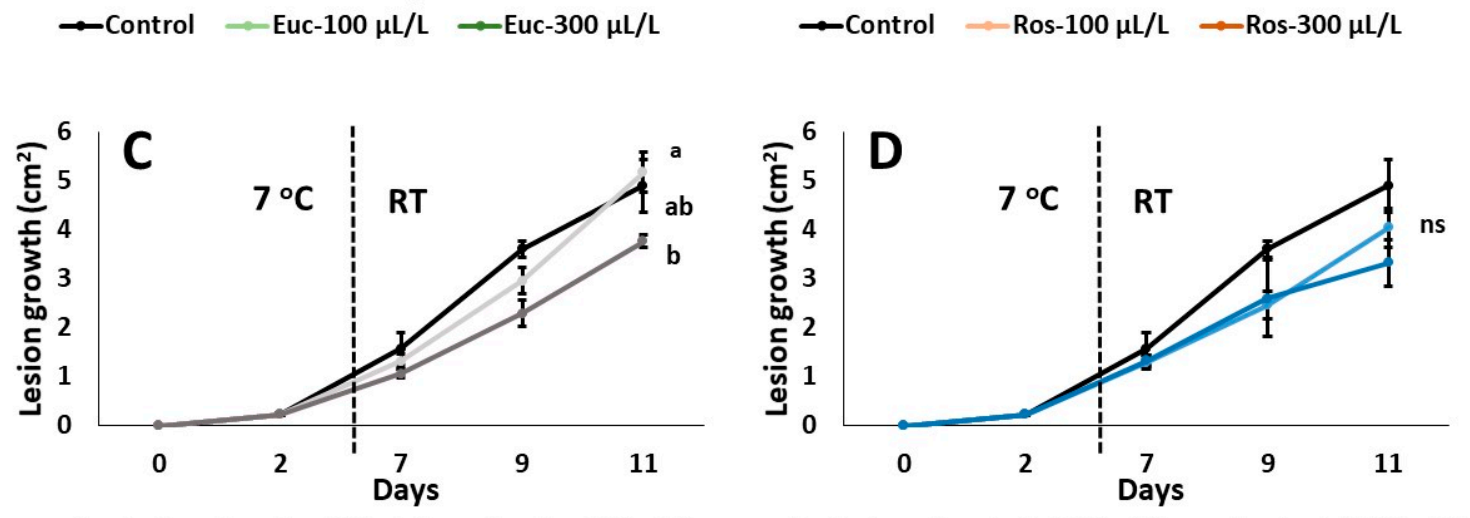

$\rightarrow$ Control $\rightarrow$ Euc+Ros-100 $\mu \mathrm{L} / \mathrm{L} \rightarrow$ Euc+Ros-300 $\mu \mathrm{L} / \mathrm{L}$

$\rightarrow$ Control $\rightarrow$ Eucalyptol-100 $\mu \mathrm{L} / \mathrm{L} \rightarrow$ Eucalyptol-300 $\mu \mathrm{L} / \mathrm{L}$

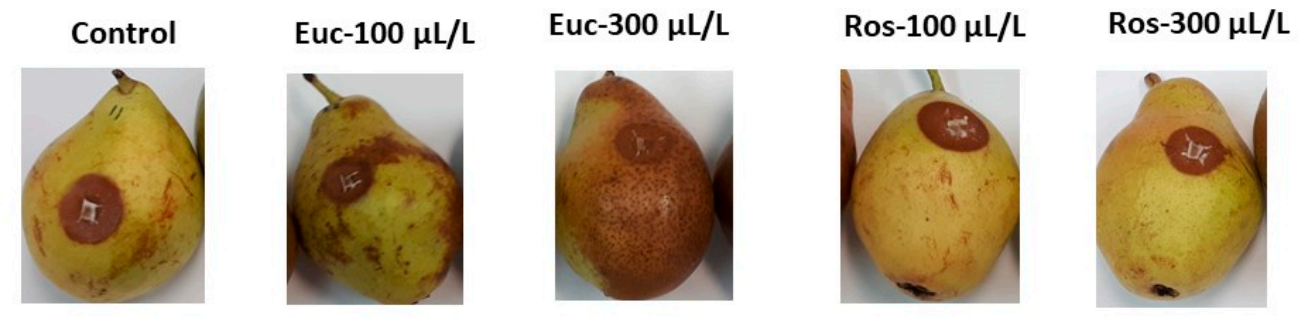

Euc-Ros-100 $\mu \mathrm{L} / \mathrm{L}$ Euc-Ros-300 $\mu \mathrm{L} / \mathrm{L}$ Eucalyptol-100 $\mu \mathrm{L} / \mathrm{L} \quad$ Eucalyptol-300 $\mu \mathrm{L} / \mathrm{L}$
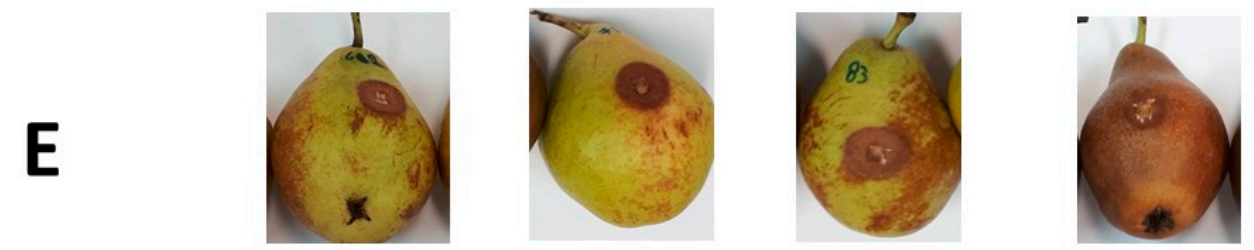

Figure 5. Effects of (A) eucalyptus EO (Euc), (B) rosemary EO (Ros), (C) their 50:50 mixture (Euc + Ros) and (D) eucalyptol on lesion growth of P. expansum grown on pear fruits stored at $7{ }^{\circ} \mathrm{C}$ for 5 days and subsequently at RT up to 15 days. Significant differences $(p<0.05)$ among treatments are represented with different Latin letters; ns indicates no significant differences among the treatments, on the last day. (E) Representative image is also presented.

\subsubsection{Effects on Fruit Quality Attributes}

Apple and pear fruit quality attributes were examined in the current study as presented in Tables 1 and 2. The combination of Euc + Ros at $300 \mu \mathrm{L} / \mathrm{L}$, eucalyptus EO (Euc-100 $\mu \mathrm{L} / \mathrm{L}$ and Euc-300 $\mu \mathrm{L} / \mathrm{L}$ ) and eucalyptol at $300 \mu \mathrm{L} / \mathrm{L}$ resulted in increased respiration rate of apple fruits compared to the non-treated ones (control). On the other hand, treatment with rosemary EO (at 100 and $300 \mu \mathrm{L} / \mathrm{L}$ ), Euc + Ros-100 $\mu \mathrm{L} / \mathrm{L}$ and Eucalyptol$100 \mu \mathrm{L} / \mathrm{L}$ did not significantly affect the respiration rate of apple fruits opposed to the control (Table 1). Moreover, respiration for control samples was found to decrease after 15 days of storage in comparison to the initial day (day 0 ). 


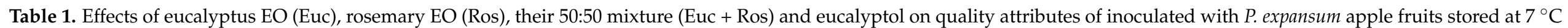
for 8 days and subsequently at RT up to 15 days.

\begin{tabular}{|c|c|c|c|c|c|c|c|c|c|c|c|c|}
\hline \multirow[b]{2}{*}{ Treatment } & \multicolumn{2}{|c|}{ Respiration $(\mathrm{mL} \mathrm{CO} / \mathrm{kg} / \mathrm{h})$} & \multicolumn{2}{|c|}{ Firmness (N) } & \multicolumn{2}{|c|}{ TSS ( ${ }^{\circ}$ Brix) } & \multicolumn{2}{|c|}{ TA (g malic acid/L) } & \multicolumn{2}{|c|}{ TSS/TA Ratio } & \multicolumn{2}{|c|}{ AA (g/100 g) } \\
\hline & 0 & 15 & 0 & 15 & 0 & 15 & 0 & 15 & 0 & 15 & 0 & 15 \\
\hline Control & $7.79 \pm 0.24 \mathrm{~A}$ & $4.79 \pm 0.31 \mathrm{cB}$ & $19.84 \pm 0.63 \mathrm{~A}$ & $18.40 \pm 1.14 \mathrm{abA}$ & $10.63 \pm 0.35 \mathrm{~A}$ & $8.53 \pm 0.75 \mathrm{aA}$ & $7.30 \pm 0.25 \mathrm{~A}$ & $3.01 \pm 0.14 \mathrm{aB}$ & $1.46 \pm 0.08 \mathrm{~A}$ & $2.82 \pm 0.12 \mathrm{cA}$ & $1.27 \pm 0.01 \mathrm{~A}$ & $1.25 \pm 0.70 \mathrm{aA}$ \\
\hline Euc-100 $\mu \mathrm{L} / \mathrm{L}$ & & $15.36 \pm 0.39 \mathrm{~b}$ & & $18.63 \pm 0.95 \mathrm{ab}$ & & $8.43 \pm 0.12 \mathrm{a}$ & & $1.85 \pm 0.17 \mathrm{~d}$ & & $4.64 \pm 0.40 \mathrm{~b}$ & & $1.06 \pm 0.21 \mathrm{a}$ \\
\hline Ros- $100 \mu \mathrm{L} / \mathrm{L}$ & & $5.15 \pm 1.94 c$ & & $18.69 \pm 0.47 \mathrm{ab}$ & & $8.97 \pm 0.22 \mathrm{a}$ & & $2.66 \pm 0.08 \mathrm{ab}$ & & $3.38 \pm 0.09 c$ & & $1.27 \pm 0.00 \mathrm{a}$ \\
\hline Ros-300 $\mu \mathrm{L} / \mathrm{L}$ & & $6.26 \pm 0.71 \mathrm{c}$ & & $20.59 \pm 0.59 \mathrm{ab}$ & & $8.30 \pm 0.50 \mathrm{a}$ & & $2.53 \pm 0.15 b c$ & & $3.29 \pm 0.17 c$ & & $1.48 \pm 0.21 \mathrm{a}$ \\
\hline Euc + Ros-100 $\mu \mathrm{L} / \mathrm{L}$ & & $7.48 \pm 1.08 c$ & & $21.24 \pm 0.21 \mathrm{a}$ & & $9.00 \pm 0.56 \mathrm{a}$ & & $3.05 \pm 0.19 \mathrm{a}$ & & $3.00 \pm 0.39 c$ & & $1.27 \pm 0.01 \mathrm{a}$ \\
\hline Eucalyptol-100 $\mu \mathrm{L} / \mathrm{L}$ & & $7.07 \pm 0.24 \mathrm{c}$ & & $17.64 \pm 1.57 \mathrm{~b}$ & & $9.07 \pm 0.37 \mathrm{a}$ & & $2.69 \pm 0.15 \mathrm{ab}$ & & $3.37 \pm 0.08 \mathrm{c}$ & & $1.48 \pm 0.21 \mathrm{a}$ \\
\hline Eucalyptol-300 $\mu \mathrm{L} / \mathrm{L}$ & & $12.71 \pm 0.88 \mathrm{~b}$ & & $19.96 \pm 1.34 \mathrm{ab}$ & & $8.17 \pm 0.07 \mathrm{a}$ & & $0.98 \pm 0.01 \mathrm{e}$ & & $8.36 \pm 0.13 \mathrm{a}$ & & $1.50 \pm 0.21 \mathrm{a}$ \\
\hline
\end{tabular}

Significant differences $(p<0.05)$ among treatments are represented with small different Latin letters; differences between control day 0 and day 15 are represented with capital different Latin letters.

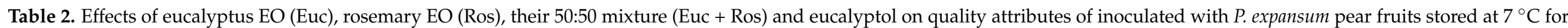
5 days and subsequently at RT up to 11 days.

\begin{tabular}{|c|c|c|c|c|c|c|c|c|c|c|c|c|}
\hline \multirow[b]{2}{*}{ Treatment } & \multicolumn{2}{|c|}{ Respiration $(\mathrm{mL} \mathrm{CO} / 2 / \mathrm{kg} / \mathrm{h})$} & \multicolumn{2}{|c|}{ Firmness $(\mathrm{N})$} & \multicolumn{2}{|c|}{ TSS (oBrix) } & \multicolumn{2}{|c|}{ TA (g malic acid/L) } & \multicolumn{2}{|c|}{ TSS/TA Ratio } & \multicolumn{2}{|c|}{ AA $(g / 100 g)$} \\
\hline & 0 & 11 & 0 & 11 & 0 & 11 & 0 & 11 & 0 & 11 & 0 & 11 \\
\hline Control & $17.82 \pm 0.51 \mathrm{~A}$ & $12.25 \pm 0.64 \mathrm{~dB}$ & $3.97 \pm 0.13 \mathrm{~A}$ & $3.12 \pm 0.64 \mathrm{aA}$ & $12.47 \pm 0.09 \mathrm{~A}$ & $10.07 \pm 1.11 \mathrm{aA}$ & $1.37 \pm 0.01 \mathrm{~A}$ & $1.60 \pm 0.17 \mathrm{aA}$ & $9.10 \pm 0.04 \mathrm{~A}$ & $6.28 \pm 0.05 \mathrm{cB}$ & $1.26 \pm 0.01 \mathrm{~A}$ & $1.26 \pm 0.01 \mathrm{abA}$ \\
\hline Euc-100 $\mu \mathrm{L} / \mathrm{L}$ & & $22.08 \pm 1.44 \mathrm{ab}$ & & $4.09 \pm 1.34 \mathrm{a}$ & & $8.47 \pm 0.68 \mathrm{ab}$ & & $1.02 \pm 0.11 \mathrm{bc}$ & & $8.52 \pm 1.23 \mathrm{ab}$ & & $1.47 \pm 0.19 \mathrm{a}$ \\
\hline Euc-300 $\mu \mathrm{L} / \mathrm{L}$ & & $17.77 \pm 0.95 b c$ & & $2.10 \pm 0.25 \mathrm{a}$ & & $8.43 \pm 0.59 \mathrm{ab}$ & & $0.66 \pm 0.09 \mathrm{~cd}$ & & $13.32 \pm 2.16 \mathrm{bc}$ & & $1.26 \pm 0.01 \mathrm{ab}$ \\
\hline Ros-100 $\mu \mathrm{L} / \mathrm{L}$ & & $15.71 \pm 2.69 \mathrm{~cd}$ & & $4.49 \pm 0.65 \mathrm{a}$ & & $9.73 \pm 0.23 \mathrm{a}$ & & $1.26 \pm 0.04 \mathrm{ab}$ & & $7.74 \pm 1.10 \mathrm{bc}$ & & $1.28 \pm 0.00 \mathrm{ab}$ \\
\hline Ros-300 $\mu \mathrm{L} / \mathrm{L}$ & & $11.27 \pm 2.35 \mathrm{~d}$ & & $2.22 \pm 0.94 \mathrm{a}$ & & $9.97 \pm 0.20 \mathrm{a}$ & & $1.13 \pm 0.10 \mathrm{~b}$ & & $8.92 \pm 0.77 \mathrm{bc}$ & & $1.26 \pm 0.01 \mathrm{ab}$ \\
\hline Euc + Ros-100 $\mu \mathrm{L} / \mathrm{L}$ & & $26.85 \pm 0.40 \mathrm{a}$ & & $2.86 \pm 0.55 \mathrm{a}$ & & $9.13 \pm 0.87 \mathrm{a}$ & & $0.93 \pm 0.04 \mathrm{bc}$ & & $9.83 \pm 0.62 \mathrm{bc}$ & & $1.03 \pm 0.21 \mathrm{~b}$ \\
\hline Eucalyptol-100 $\mu \mathrm{L} / \mathrm{L}$ & & $24.20 \pm 0.38$ a & & $4.25 \pm 1.06 \mathrm{a}$ & & $8.97 \pm 0.43 \mathrm{a}$ & & $0.90 \pm 0.18 \mathrm{bc}$ & & $11.14 \pm 2.97 \mathrm{abc}$ & & $1.25 \pm 0.01 \mathrm{ab}$ \\
\hline Eucalyptol-300 $\mu \mathrm{L} / \mathrm{L}$ & & $15.04 \pm 2.23 \mathrm{~cd}$ & & $2.03 \pm 0.94 \mathrm{a}$ & & $6.97 \pm 0.34 \mathrm{~b}$ & & $0.46 \pm 0.09 \mathrm{~d}$ & & $16.26 \pm 2.97 \mathrm{a}$ & & $1.47 \pm 0.19 \mathrm{a}$ \\
\hline
\end{tabular}

Significant differences $(p<0.05)$ among treatments are represented with small different Latin letters; differences between control day 0 and day 15 are represented with capital different Latin letters. 
Apples firmness was affected by the applied treatments is shown in Table 1 . The application of Eucalyptol-100 $\mu \mathrm{L} / \mathrm{L}$ led to decreased fruit firmness $(17.64 \mathrm{~N})$ in comparison to Euc-300 $\mu \mathrm{L} / \mathrm{L}$ and Euc + Ros-100 $\mu \mathrm{L} / \mathrm{L}$ (21.19 and 21.24 N, respectively). No significant differences were reported between control samples on the initial and end day (day 15). Apples TSS was not affected during 15 days of storage with and without the application of the natural products. Apples TA was found decreased with the applied treatments (except Euc + Ros-100 $\mu \mathrm{L} / \mathrm{L}$, Eucalyptol-100 $\mu \mathrm{L} / \mathrm{L}$ and Ros-100 $\mu \mathrm{L} / \mathrm{L})$ compared to the non-treated fruits, whilst Euc-300 $\mu \mathrm{L} / \mathrm{L}$ and Eucalyptol-300 $\mu \mathrm{L} / \mathrm{L}$ presented the lower TA values $(1.14$ and $0.98 \mathrm{~g}$ malic acid/L, respectively, Table 1$)$. The TSS/TA ration was found to increase with the application of eucalyptus EO (at 100 and $300 \mu \mathrm{L} / \mathrm{L}$ ) and Eucalyptol-300 $\mu \mathrm{L} / \mathrm{L}$ compared to the non-treated ones (Table 1). Furthermore, apple fruits (control) TA decreased during storage compared to the initial day. Apples AA content was not significantly affected with and without the applied treatments throughout storage (up to day 15, Table 1).

Table 2 shows the effects on respiration rate of pears after exposure to vapor EOs, their mixture and eucalyptol. The results showed that the application of eucalyptus (Euc$100 \mu \mathrm{L} / \mathrm{L}$ and Euc-300 $\mu \mathrm{L} / \mathrm{L}$ ), its combination with rosemary (Euc + Ros-100 $\mu \mathrm{L} / \mathrm{L}$ and Euc + Ros-300 $\mu \mathrm{L} / \mathrm{L}$ ) and Eucalyptol-100 $\mu \mathrm{L} / \mathrm{L}$ increased the respiration rate of pears compared to the control (Table 2). Furthermore, pears respiration rate for control (non-treated) samples decreased at the end of storage 9 (day 11) as to the value on the initial day.

Pear fruits' firmness was not affected during storage (up to 11 days) with or without the treatments, as illustrated in Table 2. Regarding TSS of pear fruits, all treatments (except Eucalyptol-100 $\mu \mathrm{L} / \mathrm{L}$ ) presented similar values to the non-treated fruits (Table 2). Moreover, no significant differences were reported between the control samples on initial and end day (day 11). As shown in Table 2, all applied treatments (except Ros-100 $\mu \mathrm{L} / \mathrm{L}$ ) decreased TA of pear fruits, while Eucalyptol-300 $\mu \mathrm{L} / \mathrm{L}$ and Euc-300 $\mu \mathrm{L} / \mathrm{L}$ resulted to lower TA values ( 0.46 and $0.66 \mathrm{~g}$ malic acid/L, respectively). No significant differences were reported between the non-treated (control) samples on the initial and end day (day 11) (Table 2). The TSS/TA ratio was found to increase with the application of Euc- $100 \mu \mathrm{L} / \mathrm{L}$ and Eucalyptol$300 \mu \mathrm{L} / \mathrm{L}$ compared to control, whereas a decrease in TSS/TA ratio was observed for the non-treated samples after 11 days of storage compared to the initial day (Table 2). The effects of pears AA content did not significantly differ between the applied treatments and the non-treated fruits (control) at day 11, whilst Euc + Ros-100 $\mu \mathrm{L} / \mathrm{L}$ presented lower AA content $(1.03 \mathrm{~g} / 100 \mathrm{~g})$ in comparison to Euc-100 $\mu \mathrm{L} / \mathrm{L}$ and Eucalyptol-300 $\mu \mathrm{L} / \mathrm{L}$ (1.47 and $1.47 \mathrm{~g} / 100 \mathrm{~g}$, respectively) (Table 2). On the other hand, no significant differences were reported between the non-treated (control) samples on the initial and end day (day 11).

The panelist evaluation is presented at Table 3. In apples, aroma and appearance and as a consequence fruit marketability decreased at the concentration of $300 \mu \mathrm{L} / \mathrm{L}$ when eucalyptus oil or eucalyptol was used, while rosemary EO maintained aroma, appearance and marketability to similar levels as the control (Table 3). Similar observations were made for pears as in apples.

\subsubsection{Damage Index (Hydrogen Peroxide and Lipid Peroxidation)}

The effects of the two EOs, their mixture and eucalyptol vapor application on apple fruits $\mathrm{H}_{2} \mathrm{O}_{2}$ levels are presented in Table 4. The exposure of apple fruits in Euc + Ros-300 $\mu \mathrm{L} / \mathrm{L}$ exhibited higher $\mathrm{H}_{2} \mathrm{O}_{2}$ levels $(0.10 \mu \mathrm{mol} / \mathrm{g})$ compared to the control, Euc$300 \mu \mathrm{L} / \mathrm{L}, \operatorname{Ros}-100 \mu \mathrm{L} / \mathrm{L}$ and Eucalyptol-300 $\mu \mathrm{L} / \mathrm{L}$ after 15 days of storage $(0.03,0.03$, 0.04 and $0.04 \mu \mathrm{mol} / \mathrm{g}$, respectively). Interestingly, no significant differences were found regarding the $\mathrm{H}_{2} \mathrm{O}_{2}$ levels of the non-treated (control) samples on the initial and end day (day 15). The application of Eucalyptol-300 $\mu \mathrm{L} / \mathrm{L}$ and Euc-300 $\mu \mathrm{L} / \mathrm{L}$ resulted in higher MDA levels compared to the other treatments (and control) on the 15th day of storage, followed by Euc-100 $\mu \mathrm{L} / \mathrm{L}$. On the other hand, treatment with Ros-300 $\mu \mathrm{L} / \mathrm{L}$ resulted to lower MDA levels of apple fruits compared to other treatments, whilst at the same time it presented no difference from the control and Ros-100 $\mu \mathrm{L} / \mathrm{L}$. Notably, MDA levels decreased 
for the non-treated (control) apple fruits on the last day of storage (day 15) compared to the initial day (Table 4).

Table 3. Effects of eucalyptus EO (Euc), rosemary EO (Ros), their 50:50 mixture (Euc + Ros) and eucalyptol on marketability (scale 1-10), aroma (scale 1-10) and appearance (scale 1-10) of inoculated with P. expansum apple and pear fruits, stored at $7^{\circ}$ for 8 and 5 days and then transferred at RT for up to 15 and 11 days, respectively.

\begin{tabular}{ccccccc}
\hline & \multicolumn{3}{c}{ Apple } & & \multicolumn{2}{c}{ Pear } \\
\hline Treatment & Aroma & Appearence & Marketability & Aroma & Appearence & Marketability \\
\hline Control & $7.75 \pm 0.25 \mathrm{a}$ & $7.75 \pm 0.28 \mathrm{a}$ & $7.75 \pm 0.28 \mathrm{a}$ & $7.25 \pm 0.25 \mathrm{ab}$ & $7.50 \pm 0.29 \mathrm{ab}$ & $7.00 \pm 0.41 \mathrm{ab}$ \\
\hline Euc-100 $\mu \mathrm{L} / \mathrm{L}$ & $7.50 \pm 0.28 \mathrm{a}$ & $5.75 \pm 0.25 \mathrm{c}$ & $6.00 \pm 0.00 \mathrm{bc}$ & $7.50 \pm 0.29 \mathrm{a}$ & $3.50 \pm 0.28 \mathrm{~d}$ & $3.25 \pm 0.25 \mathrm{c}$ \\
\hline Euc-300 $\mu \mathrm{L} / \mathrm{L}$ & $3.50 \pm 0.29 \mathrm{c}$ & $3.50 \pm 0.29 \mathrm{~d}$ & $3.50 \pm 0.29 \mathrm{~d}$ & $4.50 \pm 0.29 \mathrm{~d}$ & $2.50 \pm 0.29 \mathrm{e}$ & $1.75 \pm 0.25 \mathrm{~d}$ \\
\hline Ros-100 $\mu \mathrm{L} / \mathrm{L}$ & $7.50 \pm 0.29 \mathrm{a}$ & $7.50 \pm 0.28 \mathrm{a}$ & $7.50 \pm 0.29 \mathrm{a}$ & $7.50 \pm 0.29 \mathrm{a}$ & $7.50 \pm 0.29 \mathrm{ab}$ & $7.75 \pm 0.25 \mathrm{a}$ \\
\hline Ros-300 $\mu \mathrm{L} / \mathrm{L}$ & $7.25 \pm 0.25 \mathrm{a}$ & $7.50 \pm 0.28 \mathrm{a}$ & $7.25 \pm 0.25 \mathrm{a}$ & $7.25 \pm 0.25 \mathrm{ab}$ & $7.75 \pm 0.25 \mathrm{a}$ & $7.75 \pm 0.25 \mathrm{a}$ \\
\hline Euc + Ros-100 $\mu \mathrm{L} / \mathrm{L}$ & $7.00 \pm 0.41 \mathrm{ab}$ & $6.75 \pm 0.25 \mathrm{ab}$ & $6.75 \pm 0.25 \mathrm{ab}$ & $7.00 \pm 0.41 \mathrm{abc}$ & $7.00 \pm 0.41 \mathrm{ab}$ & $6.50 \pm 0.29 \mathrm{~b}$ \\
\hline Euc + Ros-300 $\mu \mathrm{L} / \mathrm{L}$ & $6.25 \pm 0.25 \mathrm{~b}$ & $6.00 \pm 0.41 \mathrm{bc}$ & $5.75 \pm 0.25 \mathrm{c}$ & $6.50 \pm 0.29 \mathrm{bc}$ & $6.75 \pm 0.25 \mathrm{~b}$ & $6.75 \pm 0.25 \mathrm{~b}$ \\
\hline Eucalyptol-100 $\mu \mathrm{L} / \mathrm{L}$ & $6.25 \pm 0.25 \mathrm{~b}$ & $6.75 \pm 0.25 \mathrm{ab}$ & $6.75 \pm 0.25 \mathrm{ab}$ & $6.25 \pm 0.25 \mathrm{c}$ & $4.50 \pm 0.29 \mathrm{c}$ & $3.75 \pm 0.25 \mathrm{c}$ \\
\hline Eucalyptol-300 $\mu \mathrm{L} / \mathrm{L}$ & $3.25 \pm 0.25 \mathrm{c}$ & $1.25 \pm 0.25 \mathrm{e}$ & $1.25 \pm 0.25 \mathrm{e}$ & $3.20 \pm 0.20 \mathrm{~d}$ & $1.00 \pm 0.00 \mathrm{f}$ & $1.00 \pm 0.00 \mathrm{~d}$ \\
\hline
\end{tabular}

Significant differences $(p<0.05)$ among treatments are represented with small different Latin letters.

Table 4. Effects of eucalyptus EO (Euc), rosemary EO (Ros), their 50:50 mixture (Euc + Ros) and eucalyptol on damage index $\left(\mathrm{H}_{2} \mathrm{O}_{2}\right.$ and MDA) of inoculated with P. expansum apple fruits stored at $7^{\circ} \mathrm{C}$ for 8 days and subsequently at RT up to 15 days.

\begin{tabular}{|c|c|c|c|c|}
\hline \multirow[b]{2}{*}{ Treatment } & \multicolumn{2}{|c|}{$\mathrm{H}_{2} \mathrm{O}_{2}(\mu \mathrm{mol} / \mathrm{g})$} & \multicolumn{2}{|c|}{ MDA (nmol/g) } \\
\hline & 0 & 15 & 0 & 15 \\
\hline Control & $0.04 \pm 0.00 \mathrm{~A}$ & $0.03 \pm 0.01 \mathrm{bA}$ & $56.98 \pm 0.92 \mathrm{~A}$ & $53.84 \pm 1.36 \mathrm{deB}$ \\
\hline Euc-100 $\mu \mathrm{L} / \mathrm{L}$ & & $0.08 \pm 0.00 \mathrm{ab}$ & & $75.40 \pm 2.22 \mathrm{~b}$ \\
\hline Euc-300 $\mu \mathrm{L} / \mathrm{L}$ & & $0.03 \pm 0.01 \mathrm{~b}$ & & $83.20 \pm 2.78 \mathrm{a}$ \\
\hline Ros-100 $\mu \mathrm{L} / \mathrm{L}$ & & $0.04 \pm 0.00 \mathrm{~b}$ & & $59.02 \pm 2.00 \mathrm{cde}$ \\
\hline Ros-300 $\mu \mathrm{L} / \mathrm{L}$ & & $0.05 \pm 0.02 \mathrm{ab}$ & & $52.73 \pm 0.88 \mathrm{e}$ \\
\hline Euc + Ros-100 $\mu \mathrm{L} / \mathrm{L}$ & & $0.04 \pm 0.01 \mathrm{ab}$ & & $60.90 \pm 1.98 c$ \\
\hline Euc + Ros-300 $\mu \mathrm{L} / \mathrm{L}$ & & $0.10 \pm 0.02 \mathrm{a}$ & & $59.65 \pm 2.85 \mathrm{~cd}$ \\
\hline Eucalyptol-100 $\mu \mathrm{L} / \mathrm{L}$ & & $0.04 \pm 0.02 \mathrm{ab}$ & & $60.06 \pm 1.71 \mathrm{~cd}$ \\
\hline Eucalyptol-300 $\mu \mathrm{L} / \mathrm{L}$ & & $0.04 \pm 0.01 \mathrm{~b}$ & & $83.85 \pm 2.87 \mathrm{a}$ \\
\hline
\end{tabular}

Significant differences $(p<0.05)$ among treatments are represented with small different Latin letters; differences between control day 0 and day 15 are represented with capital different Latin letters.

Table 5 shows the effects of the applied treatments on $\mathrm{H}_{2} \mathrm{O}_{2}$ levels of pear fruits after 11 days of storage. The application of Euc- $100 \mu \mathrm{L} / \mathrm{L}$ and Ros- $100 \mu \mathrm{L} / \mathrm{L}$ increased $\mathrm{H}_{2} \mathrm{O}_{2}$ levels compared to other treatments; while Ros- $300 \mu \mathrm{L} / \mathrm{L}$ resulted in lower $\mathrm{H}_{2} \mathrm{O}_{2}$ levels $(0.06 \mu \mathrm{mol} / \mathrm{g})$ than Euc-100 $\mu \mathrm{L} / \mathrm{L}$, Ros- $100 \mu \mathrm{L} / \mathrm{L}$ and Euc + Ros-300 $\mu \mathrm{L} / \mathrm{L}(0.15,0.16$ and $0.11 \mu \mathrm{mol} / \mathrm{g}$, respectively). No significant differences regarding the $\mathrm{H}_{2} \mathrm{O}_{2}$ levels of the non-treated (control) samples on the initial and end day (day 11) (Table 5). As shown in Table 5, exposure to Ros-300 $\mu \mathrm{L} / \mathrm{L}$ resulted in higher MDA levels compared to other treatments (except Eucalyptol- $100 \mu \mathrm{L} / \mathrm{L}$ ), whilst Euc- $100 \mu \mathrm{L} / \mathrm{L}$ decreased MDA levels of pear fruits compared to other treatments (except Ros-100 $\mu \mathrm{L} / \mathrm{L}$ ). No significant differences regarding the $\mathrm{H}_{2} \mathrm{O}_{2}$ levels of the non-treated (control) samples on the initial and end day (day 11) (Table 5). 
Table 5. Effects of eucalyptus EO (Euc), rosemary EO (Ros), their 50:50 mixture (Euc + Ros) and eucalyptol on damage index $\left(\mathrm{H}_{2} \mathrm{O}_{2}\right.$ and MDA) of inoculated with P. expansum pear fruits stored at $7^{\circ} \mathrm{C}$ for 5 days and subsequently at RT up to 11 days.

\begin{tabular}{|c|c|c|c|c|}
\hline \multirow[b]{2}{*}{ Treatment } & \multicolumn{2}{|c|}{$\mathrm{H}_{2} \mathrm{O}_{2}(\mu \mathrm{mol} / \mathrm{g})$} & \multicolumn{2}{|c|}{ MDA (nmol/g) } \\
\hline & $\mathbf{0}$ & 11 & 0 & 11 \\
\hline Control & $0.08 \pm 0.01 \mathrm{~A}$ & $0.08 \pm 0.01 \mathrm{bcA}$ & $88.11 \pm 2.26 \mathrm{~A}$ & $89.63 \pm 2.57 \mathrm{deA}$ \\
\hline Euc-100 $\mu \mathrm{L} / \mathrm{L}$ & & $0.15 \pm 0.02 \mathrm{a}$ & & $75.15 \pm 0.95 \mathrm{f}$ \\
\hline Euc-300 $\mu \mathrm{L} / \mathrm{L}$ & & $0.09 \pm 0.01 \mathrm{bc}$ & & $99.25 \pm 4.27 \mathrm{~cd}$ \\
\hline Ros-100 $\mu \mathrm{L} / \mathrm{L}$ & & $0.16 \pm 0.02 \mathrm{a}$ & & $78.71 \pm 2.18$ ef \\
\hline Ros-300 $\mu \mathrm{L} / \mathrm{L}$ & & $0.06 \pm 0.01 c$ & & $124.84 \pm 1.51 \mathrm{a}$ \\
\hline Euc + Ros-100 $\mu \mathrm{L} / \mathrm{L}$ & & $0.09 \pm 0.01 \mathrm{bc}$ & & $93.94 \pm 2.81 \mathrm{~cd}$ \\
\hline Euc + Ros-300 $\mu \mathrm{L} / \mathrm{L}$ & & $0.11 \pm 0.01 b$ & & $88.95 \pm 4.06 \mathrm{de}$ \\
\hline Eucalyptol-100 $\mu \mathrm{L} / \mathrm{L}$ & & $0.09 \pm 0.03 \mathrm{bc}$ & & $114.45 \pm 2.91 \mathrm{ab}$ \\
\hline Eucalyptol-300 $\mu \mathrm{L} / \mathrm{L}$ & & $0.07 \pm 0.00 \mathrm{bc}$ & & $104.64 \pm 2.82 \mathrm{bc}$ \\
\hline
\end{tabular}

Significant differences $(p<0.05)$ among treatments are represented with small different Latin letters; differences between control day 0 and day 15 are represented with capital different Latin letters.

\section{Discussion}

Great losses of fruits (including apples and pears) have been attributed to the development of postharvest diseases caused by fungal pathogens (i.e., B. cinerea, P. expansum). The use of EOs and natural compounds for the control of fungal growth on fruits has shown encouraging results, however not many studies have included the effects on the quality attributes and/or fruit tissue response to such treatments against fungal pathogens $[7,18,22,27,31,32]$.

In the present study, the in vitro exposure of $P$. expansum in volatiles of eucalyptus and rosemary EO, their mixture and eucalyptol has shown decreased colony growth with the application of Euc- $300 \mu \mathrm{L} / \mathrm{L}$, Ros-300 $\mu \mathrm{L} / \mathrm{L}$, Euc + Ros (100 and $300 \mu \mathrm{L} / \mathrm{L})$. These observations might be attributed to the synergistic action of the two EOs various compounds and not from their main common component (eucalyptol) since no effects on fungal colony growth were reported by the eucalyptol application. The synergistic, additive and/or antagonistic effects of EOs mixtures mainly derive from the interactions between their components (main and less abundant) [33]. Moreover, spore production was stimulated by Ros- $100 \mu \mathrm{L} / \mathrm{L}$ compared to the higher concentration (Ros-300 $\mu \mathrm{L} / \mathrm{L}$ ), while Euc + Ros and eucalyptol (at both concentrations) resulted in lower spore germination compared to non-treated samples. Since spore production was not affected by pure eucalyptol, the results from the exposure in rosemary EO are not possibly related to the main compound of this EO (i.e., eucalyptol) but to the action of other compounds present in rosemary such as camphor and $\alpha$-pinene. The antimicrobial activity (antibacterial and antifungal properties) of these two compounds have been previously proven [34-36]. These results indicate that since the key player in this case is not eucalyptol (the main component), we might be able with further assessment to enhance the levels of the other components of rosemary EO by increasing its presence in the mixture. For example, a ratio of Euc-Ros of 25:75\% $(v / v)$ could possibly give more encouraging results in comparison to the present ration used in this study $(50: 50 \% v / v)$. In addition, it seems that the medium concentration of eucalyptol indicated at a $61 \%$ content of eucalyptol (contained in the EOs mixture and pure eucalyptol) decreased spore production compared to the EOs when used alone. This could have resulted from the antifungal activity of eucalyptol which is related to concentration responses, as has been previously shown [37]. It has been reported that eucalyptol (at concentrations: $0.24,0.426$ and $1 \%$ ) possesses antifungal properties and can inhibit in vitro the mycelium growth of plant pathogens such as Fusarium subglutinans, Fusarium cerealis, Fusarium verticillioides, Fusarium proliferatum, Fusarium oxysporum, Fusarium sporotrichioides, 
Aspergillus tubingensis, Aspergillus carbonarius, Alternaria alternata and Penicillium sp. [21]. Combrinck et al. [15] showed that eucalyptus as well as eucalyptol (commonly known also as 1,8-cineole) were able to control and decrease the growth of fruit postharvest fungal pathogens such as Alternaria citrii, B. cinerea and Penicillium digitatum. In addition, Katooli et al. [16] reported in vitro antifungal activity of eucalyptus EO (at concentrations: $25-100 \% v / v$ ) against P. digitatum, Aspergillus flavus, Colletotrichum gloeosporioides. Moreover, a previous study showed the antifungal activity of eucalyptus EO and extracts against Aspergillus sp. (up to $12.9 \%$ growth inhibition) [38]. The growth of $P$. expansum was inhibited in vitro (up to $80 \%$ ) after exposure to $1000 \mu \mathrm{L} / \mathrm{L}$ rosemary EO, whilst $100 \mu \mathrm{L} / \mathrm{L}$ of rosemary EO were not able to reduce the growth of P. expansum, indicating the antimicrobial effectiveness of the $\mathrm{EO}$ is concentration dependent, among other factors (i.e., time, application method, microorganisms etc.) [18]. It is worthy of mention that eucalyptus oil was proved to have fungistatic action at lower concentrations and fungicidal action at higher concentrations [39]. Molecular basis studies would be valuable to understand the secondary metabolisms and putative mechanisms involved.

The application of natural products (plant extracts and EOs) for postharvest preservation has been extensively assessed. Apples and pears are among the most commonly consumed fruits and their high numbers increase the awareness of the food industry to meet the needs of consumers for the production of safe, high nutritional value and free of postharvest diseases fresh produce. In the present study the application of Euc-300 $\mu \mathrm{L} / \mathrm{L}$ in apples resulted in lower lesion growth of P. expansum, whilst Euc- $100 \mu \mathrm{L} / \mathrm{L}$ and Ros$100 \mu \mathrm{L} / \mathrm{L}$ showed to stimulate fungal growth. These observations are in accordance with a previous study that showed that increased rosemary EO concentrations $(500 \mu \mathrm{L} / \mathrm{L})$ resulted in lower lesion growth of P. expansum on 'Fuji' apples (up to $55 \%$ growth reduction) stored up to 30 days [18]. The above findings in our study can be reflecting the antifungal efficacy of EO-containing eucalyptol, as eucalyptus and rosemary EO, is related to the concentration of the EO applied, which actually affecting the levels of the eucalyptol in the treatments. On the other hand, Euc + Ros-300 $\mu \mathrm{L} / \mathrm{L}$ resulted in decreased lesion growth in pear fruits compare to the lower concentration (Euc + Ros-100 $\mu \mathrm{L} / \mathrm{L}$ ). It can be assumed that the synergism between the components of the two EO in the mixture could be possibly the reason for the decrease of fungal growth in this case, since the EOs when they were applied alone did not have an effect on lesion growth. Peralta-Ruiz et al. [7] mentioned that treated pear fruits with rue (Ruta graveolens L.) EO and chitosan were found to present less susceptible to the development of postharvest diseases compared to the non-treated fruits and at the same time, the process of ripening enabled the development of fungal growth. In our study, lesion growth (for both fruits) was found to be slower during storage at chilled temperature $\left(7^{\circ} \mathrm{C}\right)$ but stimulated when fruits were stored at RT. The simulation of fungal growth at RT after exposure to refrigerated temperature has also been shown in a previous study with blue mold-inoculated apples, after exposure to rosemary EO $(500 \mu \mathrm{L} / \mathrm{L})$. In that study, the rosemary EO resulted up to $35 \%$ fungal inhibition after five days of storage at RT [18]. The same study also indicated that the in vitro growth inhibition of P. expansum was more evident compared to the in vivo observations [18]. This indicates the possible interactive effects that fruit components might have to the fungal growth. Moreover, the different effects between the development of P. expansum on the two fruits might be attributed to the fact that pears are more susceptible fruits during storage than apples. At the same time, these observations might also be caused by the possible interactions of EOs with the fruit matrices [40]. It has been reported that high levels of EOs might adversely affect quality-related attributes of fresh produce with decrease on sensory properties (i.e., aroma, taste, color) [12].

Our observations showed that respiration rate of apples increased with the vapor application of Euc + Ros $300 \mu \mathrm{L} / \mathrm{L}$, eucalyptus EO and Eucalyptol $300 \mu \mathrm{L} / \mathrm{L}$, indicating increased metabolic activity of the fruit itself. This is in line with the fruit browning and decreased marketability and appearance of apples. On the contrast, Rabiei et al. [5] reported that thyme and lavender EO on 'Jonagold' apples decreased fruit's ethylene 
production, respiration and metabolic activity. This might be attributed to the different EOs applied and/or even the different fruit variety. Moreover, in the present study, pear fruit respiration rate increased with the application of eucalyptus EO, Euc + Ros and Eucalyptol-100 $\mu \mathrm{L} / \mathrm{L}$. Pears are more sensitive to increasing ethylene and carbon dioxide $\left(\mathrm{CO}_{2}\right)$ emissions compared to apples, thus the accumulation of $\mathrm{CO}_{2}$ during storage might accelerate fruit senescence $[7,41]$, and making pear fruit lasting lesser in postharvest. PeraltaRuiz et al. [7] reported increased respiration of pear fruits treated with rue EO (concentration up to $1.5 \%$ ) combined with chitosan after 21 days of storage, whilst controlling fruit decay. For both commodities examined in the present work, it can be assumed that the application of high and medium eucalyptol levels (eucalyptus EO, mixture and pure eucalyptol) caused an increase fruit metabolism (increasing respiration rate). Eucalyptol has been previously shown to affect the metabolism of tomato fruits [42]. On the other hand, in the present study, a decrease of $\mathrm{CO}_{2}$ production on the control samples was observed for both fruits assessed at the end of storage period (15 and 11 days for apples and pears, respectively). This might be related to the increased climacteric respiration observed at earlier storage period, overcoming the climacteric peak and then followed by respiration rates decreases.

Softening is a process occurring during fruit ripening linked with increased metabolic rate and respiration, water loss and breakdown of the enzymatic cell wall of plant cells [43]. Apple firmness was decreased with the application of Eucalyptol-100 $\mu \mathrm{L} / \mathrm{L}$ compared to Euc-300 $\mu \mathrm{L} / \mathrm{L}$, Eucalyptol-300 $\mu \mathrm{L} / \mathrm{L}$ and Euc + Ros-100 $\mu \mathrm{L} / \mathrm{L}$, resulting in fruit softening. Fruit firmness maintenance is related to the disease expansion, as the fungi inhibitory effects of eucalyptus EO (mainly) which decreased lesion growth on apple fruits infected surface and retained fruit firmness. On the other hand, no significant differences on pear fruits firmness were reported in our study. Peralta-Ruiz et al. [7] also reported no significant differences on pears firmness treated with rue EO and chitosan, even after 21 days of storage at $18{ }^{\circ} \mathrm{C}$.

Apples TSS were not significantly affected by the applications, whilst also pears TSS were not influenced by the treatments (except Eucalyptol $100 \mu \mathrm{L} / \mathrm{L}$, which showed lower value than the control). A study by Vieira et al. [18] showed that the application of rosemary, cinnamon, citronella and clove EOs (concentrations: 20, 100 and $500 \mu \mathrm{L} / \mathrm{L}$ ) on inoculated with P. expansum 'Fuji' apples, did not affect the TSS and TA of fruits (among other quality attributes). In our study, the TA of apple fruits decreased with the all the applied treatments (except Euc + Ros-100 $\mu \mathrm{L} / \mathrm{L}$, Eucalyptol-100 $\mu \mathrm{L} / \mathrm{L}$ and Ros-100 $\mu \mathrm{L} / \mathrm{L}$ ). However, Vieira et al. [18] reported no significant differences on apples TA with the application of rosemary, cinnamon, citronella and clove EOs. Similarly, Tzortzakis [22] also did not report significant differences on TA of tomatoes and strawberries exposed to eucalyptus and cinnamon vapors for up to 10 days. For pear fruits, a decrease in TA was also reported with all the applied treatments (Eucalyptol-300 $\mu \mathrm{L} / \mathrm{L}$ and Euc-300 $\mu \mathrm{L} / \mathrm{L}$ presented the lowest values). During shelf life and ripening process the TA of fruit decreases due to the sugar accumulation, fruits became less acid as ripen [44]. The results in our study might derive by the increase of fruit metabolism with the application of high and medium eucalyptol levels (as contained in eucalyptus EO, mixture and pure eucalyptol at high concentrations) and the fruit ripening during storage of the apple fruits. Peralta-Ruiz et al. [7] reported an increase/maintenance in TA of pears with the application of rue EO in combination with chitosan, compared to the non-treated ones after 21 days of storage, highlighting the delay ripening of the fruits. These observations might be attributed to the different EOs, applied, the method of application, the product being applied to, and the conditions of storage, among others. Furthermore, in the present study, it was found that high eucalyptol levels (i.e., contained in eucalyptus EO) and pure eucalyptol (Eucalyptol-300 $\mu \mathrm{L} / \mathrm{L}$ ) lead to an increase of the TSS/TA ratio on both commodities compared to rosemary EO and the mixture of the two EOs tested. These findings might be related to the fact that the TA of both fruits was decreased with the application of products with high eucalyptol content (eucalyptus EO, mixture of the two EOs and pure Eucalyptol), and therefore the TSS/TA ratio was increased. The content AA in EO-treated apples and pears did not significantly differ from the non-treated ones, however pears exposed to Euc + Ros-100 $\mu \mathrm{L} / \mathrm{L}$ presented 
lower AA content than Euc-100 $\mu \mathrm{L} / \mathrm{L}$ and Eucalyptol-300 $\mu \mathrm{L} / \mathrm{L}$ treated ones. The AA of fruits tends to decrease during the end of their storage time, lowering the nutritional value and presenting limitations on their storage and shelf-life duration. Pear fruit softens and ripens very quickly and thus more research could be done in an attempt to find innovative methods for the preservation of such a perishable commodity.

The production of $\mathrm{H}_{2} \mathrm{O}_{2}$ in apples increased with Euc + Ros- $100 \mu \mathrm{L} / \mathrm{L}$ compared to control, Euc- $300 \mu \mathrm{L} / \mathrm{L}$, Ros- $100 \mu \mathrm{L} / \mathrm{L}$ and Eucalyptol-300 $\mu \mathrm{L} / \mathrm{L}$ treated ones. Moreover, increased levels of $\mathrm{H}_{2} \mathrm{O}_{2}$ were also reported in pears treated with Euc-100 $\mu \mathrm{L} / \mathrm{L}$ and Ros-100 $\mu \mathrm{L} / \mathrm{L}$ compared to other treatments. The MDA levels in apple fruits increased with Eucalyptol-300 $\mu \mathrm{L} / \mathrm{L}$ and Euc- $300 \mu \mathrm{L} / \mathrm{L}$; while exposure to Ros- $300 \mu \mathrm{L} / \mathrm{L}$ presented lower MDA values. Pears MDA levels increased with Ros-300 $\mu \mathrm{L} / \mathrm{L}$, whereas at the same time Euc- $100 \mu \mathrm{L} / \mathrm{L}$ resulted in decreased MDA levels than all other treatments. These observations might be attributed to the fact that the plant tissue undergoes in stress, increases its metabolic rate and at the same time increases the accumulation of reactive oxygen species (ROS) such as $\mathrm{O}_{2}{ }^{-}$and $\mathrm{H}_{2} \mathrm{O}_{2}$, and this was shown by the increased stress indices, such as increased MDA $[27,45,46]$. This increased metabolism (catabolism) was evidenced in the sensorial test.

The use of EOs and natural compounds for the preservation and/or improvement of fruits quality and the elimination of postharvest diseases is very promising. However, caution should be taken for the conditions of application (concentration, time, method), since these products may negatively affect the organoleptic characteristics of fresh produce as well as they might present phytotoxicity at high concentrations $[7,44]$.

\section{Conclusions}

The natural products used in the current study (eucalyptus EO, rosemary EO, their mixture and eucalyptol) and the results from their application in vapor form on fresh apples and pears provide encouraging evidence for their use as natural fungicides in the fresh fruit industry. The results of the present study revealed that the applied natural products were able to inhibit the in vitro and in vivo growth of P. expansum on PDA medium as well as in apples and pears. The applied treatments increased the respiration rate of the fruits, whilst no significant effects in fruits quality attributes (especially TSS and TA) were reported in apples and pears by the applied treatments. However, the efficacy of the examined applications was not exactly the same for both studied fresh produce, as pear shown higher sensitivity to ripening/storage and fungi challenge. Thus, further investigation is needed during the application of EOs and natural products on fresh fruits in order to determine the optimum conditions of application for each individual product ensuring the nutritional value and organoleptic characteristics, eliminating at the same time the development of postharvest diseases. Possible EO encapsulation will provide better EO stability through evaporation and applications in storage of fresh commodities.

Author Contributions: P.X.: Investigation, methodology, data curation and writing —original draft preparation, A.C.: investigation and writing—original draft preparation, review \& editing, Z.F.R.A.: writing—review \& editing, N.T.: Conceptualization, supervision, formal analysis, writing-review \& editing, and funding acquisition, project administration. All authors have read and agreed to the published version of the manuscript.

Funding: This research was funded by PRIMA StopMedWaste project, which is funded by PRIMA, a programme supported by the European Union with co-funding by the Funding Agencies RIFCyprus, and by the BasicS Euphresco project (2020-C-353).

Institutional Review Board Statement: Not applicable.

Informed Consent Statement: Not applicable.

Acknowledgments: The authors are gratefully to the Carmit Ziv (the Volcani Center, Rishon Le Tsiyon, Israel) for contribution to the fungal isolation.

Conflicts of Interest: The authors declare no conflict of interest. 


\section{References}

1. Slavin, J.L.; Lloyd, B. Health Benefits of Fruits and Vegetables 1. Adv. Nutr. 2012, 3, 506-516. [CrossRef] [PubMed]

2. Del Río-Celestino, M.; Font, R. The health benefits of fruits and vegetables. Foods 2020, 9, 369. [CrossRef]

3. Klein, J.D.; Lurie, S. Prestorage Heating of Apple Fruit for Enhanced Postharvest Quality: Interaction of Time and Temperature. HortScience 2019, 27, 326-328. [CrossRef]

4. Saleh, M.A.; Zaied, N.S.; Maksoud, M.A.; Hafez, O.M. Application of Arabic Gum and Essential Oils as the Postharvest Treatments of Le Conte Pear Fruits during Cold Storage. Asian J. Agric. Hortic. Res. 2019, 3, 1-11. [CrossRef]

5. Rabiei, V.; Shirzadeh, E.; Rabbiangourani, H.; Sharafi, Y. Effect of thyme and lavender essential oils on the qualitative and quantitative traits and storage life of apple "Jonagold" cultivar. J. Med. Plant Res. 2011, 5, 5522-5527.

6. Shirzadeh, E.; Rabiei, V.; Sharafi, Y. Effect of calcium chloride $\left(\mathrm{CaCl}_{2}\right)$ on postharvest quality of apple fruits. Afr. J. Agric. Res. 2011, 6, 5139-5143.

7. Peralta-Ruiz, Y.; Grande-Tovar, C.D.; Navia Porras, D.P.; Sinning-Mangonez, A.; Delgado-Ospina, J.; González-Locarno, M.; Maza Pautt, Y.; Chaves-López, C. Packham's triumph pears (Pyrus communis L.) post-harvest treatment during cold storage based on chitosan and rue essential oil. Molecules 2021, 26, 725. [CrossRef]

8. Tzortzakis, N.; Borland, A.; Singleton, I.; Barnes, J. Impact of atmospheric ozone-enrichment on quality-related attributes of tomato fruit. Postharvest Biol. Technol. 2007, 45, 317-325. [CrossRef]

9. Znini, M.; Cristofari, G.; Majidi, L.; Mazouz, H.; Tomi, P.; Paolini, J.; Costa, J. Antifungal activity of essential oil from Asteriscus graveolens against postharvest phytopathogenic fungi in apples. Nat. Prod. Commun. 2011, 6, 1763-1768. [CrossRef] [PubMed]

10. Zhang, H.; Wang, L.; Dong, Y.; Jiang, S.; Zhang, H.; Zheng, X. Control of postharvest pear diseases using Rhodotorula glutinis and its effects on postharvest quality parameters. Int. J. Food Microbiol. 2008, 126, 167-171. [CrossRef]

11. Hosseini, S.; Amini, J.; Saba, M.K.; Karimi, K.; Pertot, I. Preharvest and Postharvest Application of Garlic and Rosemary Essential Oils for Controlling Anthracnose and Quality Assessment of Strawberry Fruit During Cold Storage. Front. Microbiol. 2020, 11, 1855. [CrossRef] [PubMed]

12. Frankova, A.; Smid, J.; Bernardos, A.; Finkousova, A.; Marsik, P.; Novotny, D.; Legarová, V.; Pulkrabek, J.; Kloucek, P. The antifungal activity of essential oils in combination with warm air flow against postharvest phytopathogenic fungi in apples. Food Control 2016, 68, 62-68. [CrossRef]

13. Tzortzakis, N.; Chrysargyris, A.; Sivakumar, D.; Loulakakis, K. Vapour or dipping applications of methyl jasmonate, vinegar and sage oil for pepper fruit sanitation towards grey mould. Postharvest Biol. Technol. 2016, 118, 120-127. [CrossRef]

14. Tzortzakis, N. Essential oil: Innovative tool to improve the preservation of fresh produce-A review. Fresh Prod. $2009,3,87-97$.

15. Combrinck, S.; Regnier, T.; Kamatou, G.P.P. In vitro activity of eighteen essential oils and some major components against common postharvest fungal pathogens of fruit. Ind. Crops Prod. 2011, 33, 344-349. [CrossRef]

16. Katooli, N.; Maghsodlo, R.; Razavi, S.E. Evaluation of eucalyptus essential oil against some plant pathogenic fungi. J. Plant Breed. Crop Sci. 2011, 3, 41-43.

17. Lopez-Reyes, J.G.; Spadaro, D.; Prelle, A.; Garibaldi, A.; Gullino, M.L. Efficacy of plant essential oils on postharvest control of rots caused by fungi on different stone fruits in vivo. J. Food Prot. 2013, 76, 631-639. [CrossRef]

18. Vieira, A.M.F.D.; Steffens, C.A.; Argenta, L.C.; do Amarante, C.V.T.; Oster, A.H.; Casa, R.T.; Amarante, A.G.M.; Espíndola, B.P. Essential oils for the postharvest control of blue mold and quality of "Fuji" apples. Pesqui. Agropecu. Bras. 2018, 53, 547-556. [CrossRef]

19. Mouatcho, J.C.; Tzortzakis, N.; Soundy, P.; Sivakumar, D. Bio-sanitation treatment using essential oils against E. coli O157:H7 on fresh lettuce. N. Z. J. Crop Hortic. Sci. 2017, 45, 165-174. [CrossRef]

20. Bakkali, F.; Averbeck, S.; Averbeck, D.; Idaomar, M. Biological effects of essential oils-A review. Food Chem. Toxicol. 2008, 46, 446-475. [CrossRef]

21. Morcia, C.; Malnati, M.; Terzi, V. In vitro antifungal activity of terpinen-4-ol, eugenol, carvone, 1,8-cineole (eucalyptol) and thymol against mycotoxigenic plant pathogens. Food Addit. Contam. Part A Chem. Anal. Control. Expo. Risk Assess. 2012, 29, $415-422$.

22. Tzortzakis, N.G. Maintaining postharvest quality of fresh produce with volatile compounds. Innov. Food Sci. Emerg. Technol. 2007, 8, 111-116. [CrossRef]

23. Jhalegar, M.J.; Sharma, R.R.; Singh, D. In vitro and in vivo activity of essential oils against major postharvest pathogens of Kinnow (Citrus nobilis $\times$ C. deliciosa) mandarin. J. Food Sci. Technol. 2015, 52, 2229-2237. [CrossRef]

24. Servili, A.; Feliziani, E.; Romanazzi, G. Exposure to volatiles of essential oils alone or under hypobaric treatment to control postharvest gray mold of table grapes. Postharvest Biol. Technol. 2017, 133, 36-40. [CrossRef]

25. Chrysargyris, A.; Panayiotou, C.; Tzortzakis, N. Nitrogen and phosphorus levels affected plant growth, essential oil composition and antioxidant status of lavender plant (Lavandula angustifolia Mill.). Ind. Crops Prod. 2016, 83, 577-586. [CrossRef]

26. Tzortzakis, N.G.; Economakis, C.D. Antifungal activity of lemongrass (Cympopogon citratus L.) essential oil against key postharvest pathogens. Innov. Food Sci. Emerg. Technol. 2007, 8, 253-258. [CrossRef]

27. Tzortzakis, N. Physiological and proteomic approaches to address the active role of Botrytis cinerea inoculation in tomato postharvest ripening. Microorganisms 2019, 7, 681. [CrossRef] [PubMed]

28. AOAC International. Official Methods of Analysis, 18th ed.; AOAC International: Gaithersburg, MD, USA, 2007. 
29. Loreto, F.; Velikova, V. Isoprene produced by leaves protects the photosynthetic apparatus against ozone damage, quenches ozone products, and reduces lipid peroxidation of cellular membranes. Plant Physiol. 2001, 127, 1781-1787. [CrossRef]

30. Chrysargyris, A.; Michailidi, E.; Tzortzakis, N. Physiological and biochemical responses of Lavandula angustifolia to salinity under mineral foliar application. Front. Plant Sci. 2018, 9, 489. [CrossRef]

31. Stavropoulou, A.; Loulakakis, K.; Magan, N.; Tzortzakis, N. Origanum dictamnus Oil Vapour Suppresses the Development of Grey Mould in Eggplant Fruit in Vitro. BioMed Res. Int. 2014, 2014, 562679. [CrossRef]

32. Aguilar-González, A.E.; Palou, E.; López-Malo, A. Antifungal activity of essential oils of clove (Syzygium aromaticum) and/or mustard (Brassica nigra) in vapor phase against gray mold (Botrytis cinerea) in strawberries. Innov. Food Sci. Emerg. Technol. 2015, 32, 181-185. [CrossRef]

33. Bassolé, I.H.N.; Juliani, H.R. Essential oils in combination and their antimicrobial properties. Molecules 2012, 17, 3989-4006. [CrossRef]

34. Soković, M.; Van Griensven, L.J.L.D. Antimicrobial activity of essential oils and their components against the three major pathogens of the cultivated button mushroom, Agaricus bisporus. Eur. J. Plant Pathol. 2006, 116, 211-224. [CrossRef]

35. Mokbel, A.A.; Alharbi, A.A. Antifungal effects of basil and camphor essential oils against Aspergillus flavus and A. parasiticus. Aust. J. Crop Sci. 2015, 9, 532-537.

36. da Silva, A.C.R.; Lopes, P.M.; de Azevedo, M.M.B.; Costa, D.C.M.; Alviano, C.S.; Alviano, D.S. Biological Activities of $\alpha$-Pinene and $\beta$-Pinene Enantiomers. Molecules 2012, 17, 6305-6316. [CrossRef]

37. Soković, M.D.; Brkić, D.D.; Džamić, A.M.; Ristić, M.S.; Marin, P.D. Chemical composition and antifungal activity of Salvia desoleana Atzei \& Picci essential oil and its major components. Flavour Fragr. J. 2009, 24, 83-87.

38. Javed, S.; Shoaib, A.; Mahmood, Z.; Mushtaq, S.; Iftikhar, S. Analysis of phytochemical constituents of Eucalyptus citriodora L. responsible for antifungal activity against post-harvest fungi. Nat. Prod. Res. 2012, 26, 1732-1736. [CrossRef]

39. Shahi, S.K.; Patra, M.; Shukla, A.C.; Dikshit, A. Use of essential oil as botanical-pesticide against post harvest spoilage in Malus pumilo fruits. BioControl 2003, 48, 223-232. [CrossRef]

40. Hyldgaard, M.; Mygind, T.; Meyer, R.L.; Debabov, D. Essential oils in food preservation: Mode of action, synergies, and interactions with food matrix components. Front. Microbiol. 2012, 3, 12. [CrossRef]

41. Calvo, G.; Sozzi, G.O. Improvement of postharvest storage quality of "Red Clapp's" pears by treatment with 1-methylcyclopropene at low temperature. J. Hortic. Sci. Biotechnol. 2004, 79, 930-934. [CrossRef]

42. González, L.A.; Torres, F.; Quiñones, W. Changes in Tomato Metabolism by Applying 1,8-Cineole. J. Microb. Biochem. Technol. 2015, 7. [CrossRef]

43. Bobelyn, E.; Serban, A.S.; Nicu, M.; Lammertyn, J.; Nicolai, B.M.; Saeys, W. Postharvest quality of apple predicted by NIRspectroscopy: Study of the effect of biological variability on spectra and model performance. Postharvest Biol. Technol. 2010, 55, 133-143. [CrossRef]

44. Gago, C.; Antão, R.; Dores, C.; Guerreiro, A.; Miguel, M.G.; Faleiro, M.L.; Figueiredo, A.C.; Antunes, M.D. The effect of nanocoatings enriched with essential oils on "Rocha" pear long storage. Foods 2020, 9, 240. [CrossRef] [PubMed]

45. Larrigaudiere, C.; Lentheric, I.; Pintó, E.; Vendrell, M. Short-term effects of air and controlled atmosphere storage on antioxidant metabolism in conference pears. J. Plant Physiol. 2001, 158, 1015-1022. [CrossRef]

46. Lu, X.; Ma, Y.; Liu, X. Effects of hydrogen peroxide accumulation, lipid peroxidation, and polyphenol oxidation during superficial scald development in 'Fuji' apples. Hortic. Environ. Biotechnol. 2014, 55, 299-307. [CrossRef] 